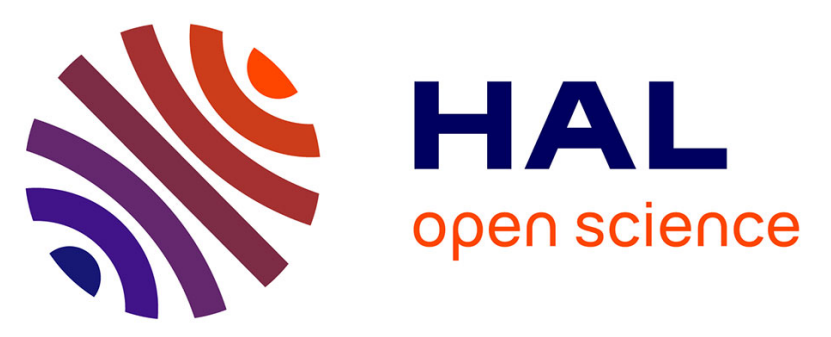

\title{
Secondary findings from whole-exome/genome sequencing evaluating stakeholder perspectives. A review of the literature
}

J. Delanne, S. Nambot, A. Chassagne, O. Putois, A. Pelissier, C. Peyron, E. Gautier, J. Thevenon, E. Cretin, A.-L. Bruel, et al.

\section{To cite this version:}

J. Delanne, S. Nambot, A. Chassagne, O. Putois, A. Pelissier, et al.. Secondary findings from wholeexome/genome sequencing evaluating stakeholder perspectives. A review of the literature. European Journal of Medical Genetics, In press, 10.1016/j.ejmg.2018.08.010 . hal-02058797

\section{HAL Id: hal-02058797 \\ https://u-bourgogne.hal.science/hal-02058797}

Submitted on 25 Oct 2021

HAL is a multi-disciplinary open access archive for the deposit and dissemination of scientific research documents, whether they are published or not. The documents may come from teaching and research institutions in France or abroad, or from public or private research centers.
L'archive ouverte pluridisciplinaire HAL, est destinée au dépôt et à la diffusion de documents scientifiques de niveau recherche, publiés ou non, émanant des établissements d'enseignement et de recherche français ou étrangers, des laboratoires publics ou privés.

\section{(ㄷ)(1) $\$$}

Distributed under a Creative Commons Attribution - NonCommerciall 4.0 International 


\section{Secondary findings from whole-exome/genome sequencing evaluating stakeholder perspectives. A review of the literature}

J. Delanne ${ }^{1}$, S. Nambot ${ }^{1,3}$, A. Chassagne ${ }^{2,4}$, A. Pelissier ${ }^{2,6}$, C. Peyron ${ }^{2,6}$, E. Gautier ${ }^{2}$, J. Thevenon $^{1,2,3}$, E. Cretin ${ }^{2,4}$, AL. Bruel ${ }^{3}$, V. Goussot ${ }^{7}$, F. Ghiringhelli ${ }^{7}$, R. Boidot ${ }^{7}$, F. TranMau-Them ${ }^{3,8}$, C. Philippe ${ }^{3,8}$, A. Vitobello ${ }^{3,8}$, L. Demougeot ${ }^{9}$, C. Vernin ${ }^{9}$, AS. Lapointe ${ }^{9}$, M. Bardou $^{10}$, M. Luu ${ }^{10}$, C. Binquet ${ }^{10}$, C. Lejeune ${ }^{10}$, L. Joly ${ }^{1}$, C. Juif ${ }^{1}$, A. Baurand ${ }^{1}$, C. Sawka ${ }^{1}$, G. Bertolone $^{1}$, Y. Duffourd ${ }^{2,3}$, D. Sanlaville ${ }^{11}$, P. Pujol ${ }^{12}$, D. Geneviève ${ }^{12}$, F. Houdayer ${ }^{11}$, C. Thauvin-Robinet ${ }^{1,2,3,7,9^{*}}$, L. Faivre ${ }^{1,2,3,7,9,12^{*}}$

1 Centre de Génétique et Centre de Référence Maladies Rares ‘Anomalies du Développement de l'Interrégion Est, Hôpital d'Enfants, CHU, Dijon, France

2 FHU TRANSLAD, Centre Hospitalier Universitaire et Université de Bourgogne-Franche Comté, Dijon, France

3 Equipe GAD «Génétique des Anomalies du Développement », UMR INSERM 1231, Université de Bourgogne, Dijon, France

4 CIC-IT Inserm 808, CHU de Besançon et Université de Bourgogne-Franche Comté, Besançon, France

5 EA 3071 SuLiSoM, Université de Strasbourg, Strasbourg, France 6 EES-LEDI, Université de Bourgogne, France

7 GIMI (Genomic and Immunotherapy Medical Institute), Centre Georges François Leclerc, Dijon, France

8 Laboratoire de génétique moléculaire et de Cytogénétique, Plateau Technique de Biologie, CHU Dijon, France

9 Filière AnDDI-Rares, Centre Hospitalier Universitaire et Université de Bourgogne-Franche Comté, Dijon, France

10 INSERM, CIC1432, module épidémiologie clinique, Dijon, France ; Centre Hospitalier Universitaire Dijon-Bourgogne, Centre d'investigation clinique, module épidémiologie clinique/essais cliniques, Dijon, France

11 CLAD Sud-Est, Hôpital Femmes Mères Enfants, Hôpitaux Civils de Lyon, Lyon, France 
12 Société Française de Médecine Prédictive et Personnalisée (SFMPP), CHU Montpellier, Montpellier, France

* These authors equally contributed in the work

The authors declare no conflict of interest.

Address for correspondence:

Laurence Faivre, MD-PhD,

Centre de Génétique et Centre de Référence Anomalies du développement et Syndromes Malformatifs, Hôpital d'Enfants, 14 rue Gaffarel, CHU Dijon, France.

Tel: $+33380295313 \quad$ Fax: +33380293266

E-mail: laurence.faivre@chu-dijon.fr

Christel Thauvin, MD-PhD,

Centre de Génétique et Centre de Référence Anomalies du développement et Syndromes Malformatifs, Hôpital d'Enfants, 14 rue Gaffarel, CHU Dijon, France.

Tel: $+33380295313 \quad$ Fax: +33380293266

E-mail: christel.thauvin@chu-dijon.fr 


\section{ABSTRACT}

With the development of next generation sequencing, beyond identifying the cause of manifestations that justified prescription of the test, other information with potential interest for patients and their families, defined as secondary findings (SF), can be provided once patients have given informed consent, in particular when therapeutic and preventive options are available. The disclosure of such findings has caused much debate. The aim of this work was to summarize all opinion-based studies focusing on SF, so as to shed light on the concerns that this question generate.

A review of the literature was performed, focusing on all PubMed articles reporting qualitative, quantitative or mixed studies that interviewed healthcare providers, participants, or society regarding this subject. The methodology was carefully analysed, in particular whether or not studies made the distinction between actionable and non-actionable SF, in a clinical or research context.

From 2010 to 2016, 39 articles were compiled. A total of 14,868 people were interviewed (1,259 participants, 6,104 healthcare providers, 7,505 representatives of society). When actionable and non-actionable SF were distinguished (20 articles), 92\% of respondents were keen to have results regarding actionable SF (participants: $88 \%$, healthcare providers: $86 \%$, society: $97 \%$ ), against $70 \%$ (participants: $83 \%$, healthcare providers: $62 \%$, society: $73 \%$ ) for non-actionable SF. These percentages were slightly lower in the specific situation of children probands.

For respondents, the notion of the «patient's choice» is crucial. For healthcare providers, the importance of defining policies for SF among diagnostic lab, learning societies and/or countries is outlined, in particular regarding the content and extension of the list of actionable genes to propose, the modalities of information, and the access to information about adultonset diseases in minors.

However, the existing literature should be taken with caution, since most articles lack a clear definition of SF and actionability, and referred to hypothetical scenarios with limited information to respondents. Studies conducted by multidisciplinary teams involving patients with access to results are sadly lacking, in particular in the medium term after the results have been given. Such studies would feed the debate and make it possible to measure the impact of such findings and their benefit-risk ratio. 


\section{KEYWORDS}

Secondary findings, Actionability, Opinion based studies, Literature Review. 


\section{INTRODUCTION}

Recent technical progress led to development of genomic medicine, which now makes it possible to sequence the genome of individuals at a reasonable cost and in a time compatible with care. This development was associated with an increase in knowledge concerning the medical significance of the variants identified. Since 2009, next generation sequencing (NGS) has become an innovative technology to analyse the DNA of an individual's genome (or its coding regions, the exome, which corresponds to $1.5 \%$ of the entire genome). NGS, and in particular, sequencing of the whole exome (WES), is now widely used in research and has led to significant advances in our understanding of the molecular bases of Mendelian diseases, which could not be determined using classical approaches. Thus, genomic medicine is based on the analysis and interpretation of genomic information in a medical context, but major obstacles need to be overcome before its full implementation.

The very recent implementation of WES for rare developmental diseases, which are particularly heterogeneous, has led to a diagnostic yield greater than $25 \%$, making it by far the most efficient individual diagnostic test for such conditions, in particular in the absence of a precise clinical diagnosis [De Ligt et al., 2012; Retterer et al., 2016; Yang et al., 2013; Yang et al., 2014]. Proof-of-concept studies suggest that whole genome sequencing (WGS) could increase the diagnostic yield to $60 \%$ for rare developmental diseases [Gilissen et al., 2014]. Despite its considerable interest in care, the implementation of WES and WGS varies widely from country to country.

Beyond the identification of pathogenic variants for the diagnosis of rare Mendelian diseases, the sequencing of an individual's genome may lead to the detection of numerous variants unrelated to the primary diagnosis for which NGS was prescribed but may be pertinent in terms of prevention for the patients and/or their families. Indeed, these variants may predispose the individual to diseases with a later onset that could be accessible to prevention or treatment, or they may provide information on the risk of transmitting a serious disease, and could thus be useful for family genetic counselling, or finally, these variants may predispose an individual to toxicity or the absence of efficacy of a given drug, and such knowledge may make it possible to adapt a treatment if necessary. These data can be particularly useful for highly medicated patients with rare diseases, whose families are deeply affected by the disease.

These variants, which correspond to findings not related to the disease for which the test was initially prescribed, were until very recently called incidental findings in the North-American literature [Green et al., 2013]. This term is no longer appropriate in cases of active screening 
for variants in certain genes. In the latest recommendations of the American College of Medical Genetics and Genomics (ACMG) and of the European Society of Human Genetics (ESHG), the term was progressively replaced by 'secondary findings' (SF) in an effort to standardise [Kalia et al., 2017; Matthijs et al., 2016].

The ACMG was the first organisation to define and propose an initial minimal list of 56 genes that were considered medically «actionable». Among these, pathogenic variants or potentially pathogenic variants must be reported by all clinical laboratories that propose WES and WGS [Green et al., 2013], unless the patient has previously refused to have access to this information_in the informed consent process (American College of Medical Genetics and Genomics 2014). In 2016, this list, which is intended to be regularly revised, was extended to 59 genes [Kalia et al., 2017]. An "actionable" gene is defined as a gene which, in the case of a pathogenic or potentially pathogenic mutation, will increase the risk of developing a genetic disease accessible to prevention or treatment, especially if the treatment is more effective if given early. Such interventions would thus improve the prognosis in terms of mortality or morbidity [Green et al., 2013]. These are essentially genes with pathogenic or probably pathogenic_variants that predispose individuals to hereditary heart diseases or cancers. Certain laboratories propose to screen for a more complete list of genes with actionable variants [Amendola et al., 2015; Dorschner et al., 2013], including genes in which pathogenic or probably pathogenic mutations have been identified in roughly $2 \%$ of patients. A few publications have proposed methods to evaluate the actionable nature of a gene, so as to complete the list of genes to target in the future depending on progress in our knowledge [Berg et al 2016; Hunter et al., 2016]. The implications in terms of healthcare organisation have been little discussed [Bennette et al., 2015], but it is clear that interpreting such findings will increase the workload of healthcare professionals as much for the clinicians as for the biologists. In term of patient management, we should highlight the risk of utilizing unnecessary health care that may not be needed, because of reduced penetrance, and that could be more harmful than beneficial.

The analysis of these variants, if requested by the patient or the patient's guardian, could become the first step in genomic medicine [Bowdin et al 2016; Manolio et al., 2015]. However, the interpretation of such variants, which are not related to the primary cause of the disease, will require additional investment from healthcare professionals, notably in terms of time. Although benefits can be derived in terms of prevention, it is a major issue to take into account the point of view of patients and more widely that of society at large. This article thus investigates the point of view of patients, of healthcare professionals and of society via a 
review of the literature on SF. We have synthesized the principal studies focusing on the return of SF, so as to shed light on the concerns that this question generates.

\section{METHODS}

The aim of this study was to synthesize all relevant studies focusing on the return of SF published in referenced scientific journals, so as to determine the principal expectations and concerns of patients, research participants, healthcare professionals and the public with regard to this issue. In this study, we generally refer to "participants" instead of "patients" because respondents in a number of these studies were not patients but research participants. To this end, in October 2016, we used the PubMed search tool with the following key words: "Incidental findings", "Secondary findings", "Ancillary findings", "Unsolicited findings", "Opportunistic findings", or "Accessory findings". These could be accompanied by accessory key words, such as: «Genetics»; «Clinical actionability»; «Whole exome sequencing»; «Healthcare provider»; «Geneticist»; «Professional»; «Society»; «Patient». The selection was limited to articles available in English or in French, to articles interviewing more than five people, and to articles that focused on the subject of secondary findings.

We chose to separate the articles into three principal categories depending on the population involved: i) participants, ii) healthcare professionals, iii) society. It is commonly admitted that point of views differs between patients/participants and healthcare professionals. We also decided to separate participant which could be directly concerned by WES/WGS and society (representing people with no direct concern in WES/WGS for health purposes) as their emotional involvement, their knowledge and personal expectations may alter their vision of WES/WGS. We then analysed each category with regard to the methodology: quantitative, qualitative, or mixed.

With the aim to make comparisons, we distinguished between actionable and non-actionable SF. For some articles, ACMG definitions was explicitly used, others simply used examples this highlight this difference, as stated in table 2. Qualitative and quantitative data were analysed separately (Table 2). Only quantitative data from quantitative or mixed article were used to calculate percentages. Qualitative studies were used as references to emphasize or counterbalance our results. In order to facilitate the reading and understanding, we decided to add to each reference in the results section their corresponding methodology: "Ql" for qualitative, "Qt" quantitative and "M" for mixed studies. As some articles focuses on different 
populations (participants/healthcare providers/society), they can use different methodology on each population. Therefore, the same reference can be classified in a different section of table 2 depending on the population of interest. Furthermore, some of the studies involved opinions regarding the return of results of SF in a research context, whereas others focused on the return of results in a diagnostic context (Table 1 and 2).

\section{RESULTS}

\section{General data (Figure 1 and 2)}

Thirty-nine articles were selected according to the criteria mentioned above (Table $1 \boldsymbol{a}, \boldsymbol{b}, \boldsymbol{c}$ ). The oldest article was published in 2010 [Meacham et al., 2010 (Q1)] (Figure 1a). Thirtythree articles were form North America, three were from Europe, and three were from Australia (Figure 1b).

Initially, we focused on the interpretation of the results (Figure 2), as it is now clear that it is essential to distinguish between opinions on the actionable or non-actionable nature of the SF. Nonetheless, as half of the articles made no difference between actionable and non-actionable $\mathrm{SF}$, the results below must be interpreted with caution. Among the 39 articles, 20 mentioned this difference, and half of them were referring to a research context whereas the other half were referring to a diagnosis context. Eleven of these referred to the ACMG list for actionability, and the other nine made use of precise examples. In these 20 articles, $92 \%$ of the persons interviewed were in favour of conveying the results for actionable SF, and 70\% were in favour for non-actionable SF (Table 2). This percentage was slightly lower when respondents were questioned about the specific case of children. In this case, $84 \%$ of persons interviewed were in favour of disclosing actionable SF to children or to their legal guardians, and $68 \%$ for non-actionable SF. The percentages were lower in a diagnostic context than in a research context (Table 2).

\section{Studies concerning patients/participants (Table 1a)}

Thirteen articles were identified, including five quantitative studies, four qualitative studies and four mixed studies (Table 1a). Altogether, there were 1259 participants in these studies (1010 in the quantitative studies, 85 in the qualitative studies, and the remaining 164 in the mixed studies) (Figure 2); 1097 index cases were adults and 162 were children. Five of the 13 studies focused on participants with cancer, for a total of 438 participants. 
Concerning the quantitative [Fernandez et al., 2014; Fernandez et al., 2015; Gray et al., 2016; Jelsig et al., 2015; Shahmirzadi et al., 2014] and mixed studies [Appelbaum et al., 2014; Gray et al., 2012; Kaphingst et al., 2016; Oberg et al., 2015], the majority of participants wished to know the SF found in the genetic investigations. When the notion of actionability was mentioned, this percentage was $88 \%$ if the SF were actionable and $83 \%$ if they were not actionable. In a diagnosis context, only one article [Shahmirzadi et al., 2013 (Qt)] focuses on the opinion of participant with $94 \%$ of them in favour of the disclosure of actionable secondary findings. In a research context, $87 \%$ of the participants were in favour of the disclosure of actionable secondary findings and $83 \%$ for non-actionable ones.

Following two studies in oncology conducted by Gray [Gray et al., 2012 (M); Gray et al., 2016 (Qt)], the strong desire of participants to learn about any type of SF showed the importance of providing high-quality information to patients to help them choose the type of secondary findings they wished to know about. A study conducted by Shahmirzadi and coll. in 2013 [Shahmirzadi et al., 2013 (Qt)] evaluated the choice of having access to SF in the first 200 patients referred to Ambry Genetics for WES following a consultation with a genetic counsellor during which information was given (162 parents of affected children and 38 adult patients). The persons whose choice were retrospectively analysed, could choose to receive the results for pathogenic or probably pathogenic variants in four categories of SF: healthy carrier of a recessive disease; predisposition to actionable later-onset diseases; actionable predisposition to cancers; predisposition to actionable childhood-onset diseases. The parents of affected children were more likely to choose to know the SF for their children (96\%) than were adult patients for SF for themselves (84\%). In 2015, Fernandez and coll. [Fernadez et al., 2015 (Qt)] re-surveyed 154 parents of children with rare diseases after a first survey 18 months earlier [Fernadez et al., 2014 (Qt)], and showed strong stability in their responses. Altogether, $85 \%$ of the parents believed that they should be given the choice to have access to SF whether actionable or not. Only $74 \%$ believed that these results should be shared with atrisk relatives. The qualitative data (Table 1a) showed that the participants wanted to be involved in the choice of variants to be disclosed. They were afraid, however, that these results would cause anxiety [Oberg et al., 2015 (M)]. In a study in 37 persons who underwent WES for a rare disease or cancer, Clift and coll. [Clift et al., 2015 (Q1)] showed that patients had great expectations with regard to these SF. The patients were interviewed on four occasions: before the first consultation with a genetic counsellor, after the first consultation with a genetic counsellor, while they were waiting for the results, and after the results had been given. One person justified the choice of knowing the results, including for non- 
actionable SF, by saying that he wanted to be sure that he wouldn't be a burden for his loved ones. Others said that it would let them contribute to research to help find a preventive or curative treatment for these diseases. The study of Sapp and coll. in 2014 [Sapp et al., 2014 (Q1)] in 25 parents of 13 children with various genetic diseases showed that $60 \%$ of parents did not want to receive the results for non-actionable SF. They said they needed more time to think about it and were concerned about the uncertainty and the worry caused by these disclosures. The question of research on the carrier status in recessive diseases was also raised, and $56 \%$ of parents preferred to leave the choice of knowing these results to their children once they became adults. In 2016, Kaphingst and coll [Kaphingst et al., 2016 (M)] conducted 60 semi-structured interviewed with young women diagnosed with breast cancer. All women were interested in receiving actionable secondary findings, also comprising pharmacogenetic variants.

\section{Studies concerning healthcare professionals (Table 1b)}

Twenty-two articles focused on the point of view of healthcare professionals (Table $1 \boldsymbol{b}$ ), eight quantitative, eight qualitative and six mixed studies. When the number was given, a total of 6104 medical geneticists, oncologists, paediatricians, genetic counsellors, genetic researchers, reviewers and other specialists were interviewed. Of these, 3031 took part in a quantitative study, 230 in a qualitative study and 2843 in a mixed study (Figure 2). When asked about their opinion on the disclosure of actionable secondary findings, healthcare providers where in favor of their return $86 \%$ of the time. Percentages were comparable in a diagnosis context $(86 \%)$ and in a research context $(91 \%)$. In the case of non-actionable secondary findings, $62 \%$ were in favour of their disclosure in a diagnosis context, but they were slightly less favourable for their disclosure in a research context $(55 \%)$.

The article by Gliwa and coll. [Gliwa et al., 2016 (Qt)] focused on non-geneticist reviewers, and $74 \%$ of respondents said they had had some experience with SF in genetics, but only $47 \%$ felt ready to disclose such findings to patients. Gray and coll. [Gray et al., 2016 (M)] focused on the point of view of oncologists, among whom $67 \%$ were not in favour of restricting the results given to patients to actionable genes only; $52 \%$ believed that patients should be given all of the results they wanted, even raw sequencing data. In this respect, Hitch and coll. [Hitch et al., 2014 (Ql)] reported that «compared with the cancer, negative information was surmountable». The study of Strong and coll. [Strong et al., 2014 (M)] included 258 paediatricians. Among these, $91 \%$ believed that actionable SF for adult-onset diseases should be given to families if they so wished and $96 \%$ believed so for actionable SF for childhood- 
onset diseases, compared with $47 \%$ for non-actionable SF. Concerning medical geneticists, overall, 95\% were prepared to disclose medically actionable SF [Lohn et al., 2013 (Qt)]. In the article of $\mathrm{Yu}$ and coll. [Yu et al., 2014 (Qt)] in which 760 American geneticists were surveyed, $85 \%$ believed that SF in ACMG genes should be given to adult patients and $74 \%$ were of this opinion for parents of affected children. Sixty-two per cent believed that SF should be given to the parents of affected children with adult-onset diseases or carrier status (62\%), and $81 \%$ believed that the preferences of patients should guide the practitioner in the choice of variants to disclose. In 2016, Middleton and coll. [Middleton et al., 2016 (M)] surveyed 533 medical geneticists, 843 non-genetic healthcare professionals and 607 genomic researchers. Ninety-two per cent of geneticists and $94 \%$ of non-geneticist healthcare professionals and genomic researchers believed that pertinent SF from sequencing should be returned to patients if they so wished. In this article, the authors distinguished between a prescription for NGS for diagnostic purposes and for research. Only 34\% maintained their position if the search for these SF could compromise the ability of researchers to analyse the primary data, in particular because of the additional workload due to the analysis of secondary findings.

Several articles converged regarding the difficulties related to the absence of national guidelines, which should remain flexible enough to be adapted to individual situations, to the evolution of knowledge, and to the choice of patients [Downing et al., 2013 (Q1); Keogh et al., 2014 (Q1); Simon et al., 2011 (Q1); Yu et al., 2014 (Qt)]. Scheuner and coll [Scheuner et al., 2014 (Qt)] identified four factors that explained the variance of opinion between healthcare professionals in their decision to disclose or not SF: the clinical and laboratory best practices, patients' preferences, the guidance for practice and the informed consent. This raises the issue of dynamic consent [Keogh et al., 2014 (Q1)]. Grove and coll [Grove et al., 2014 (Q1)] spoke of it as an iterative and flexible process with unlocking results to "take into account not only the changing interpretations of the genome, but also the changing values and contexts of patients over time".

Only three articles dealt specifically with the question of pharmacogenetics [Gray et al., 2016 (M); Grove et al., 2014 (Q1); Klitzman et al., 2013 (M)] (Table 1b).

\section{Studies concerning society at large (Table 1c)}

Nine articles were identified [Christenhusz et al., 2015 (Q1); Daack-Hirsch et al., 2013 (Q1); Flemming et al., 2015 (Qt); Haga et al., 2012 (Q1); Hufnagel et al., 2016 (Qt); Middleton et 
al., 2016 (Qt); Regier et al., 2015 (Qt); Strong et al., 2014 (M); Townsend et al., 2012 (Q1)], in which 7505 people were recruited. The vast majority were recruited in four quantitative studies (7243 respondents), 165 took part in four qualitative studies and 97 in a study employing a mixed methodology. Four articles made the distinction between actionable secondary findings and non-actionable ones. Half of them referred to a diagnosis context [Hufnagel et al., 2016 (Qt); Strong et al., 2014 (M)] and the other half to a research context [Fleming et al., 2015 (Qt); Middleton et al., 2016 (Qt)] (Figure 1c).

In their study, Middleton and coll. [Middleton et al., 2016 (Qt)] surveyed 4961 persons representing the public, of whom $83 \%$ had never had any contact with genetics (79\% lived in Ireland or the United Kingdom). In this study, surveyed participants were asked to put themselves in an hypothetical scenario of a patient who has been given a prescription for WES. It showed that $98 \%$ of participants wished to know about actionable SF and $73 \%$ also wanted the return of non-actionable SF. In the study by Fleming and coll. [Flemming et al., 2015 (Qt)] involving 800 Australian adults, 94\% wanted the return of information defined as important for their health or for the treatment of their hypothetical disease; $84 \%$ wanted information on their risk of being a healthy carrier of a hereditary genetic disease; 70\% wanted to receive «every type of SF (including non-actionable SF) ». Hufnagel and coll [Hufnagel et al., 2016 (Qt)] surveyed 282 students with scientific training aged for the most part between 12 and 18 years old. Of these, $83 \%$ wanted access to adult-onset SF that were not actionable during childhood; $72 \%$ wanted to be involved in the decision-making process; $73 \%$ thought that parents of a child less than 12 years old should have access to this information at the same time as their child. Different articles converged with regard to leaving the choice to the patient [Daack-Hirsch et al., 2013 (Q1); Strong et al., 2014 (M); Townsend et al., $2012(\mathrm{Q} 1)]$.

\section{DISCUSSION}

This review of the literature with the main opinion-based articles on SF showed that the vast majority of participants and society at large were in favour of returning actionable SF, and that the majority of doctors were prepared to screen for and disclose these actionable SF to their patients. However, the results of the studies must be interpreted with caution, since most articles referred to hypothetical scenarios. Hypothetical situations are a notoriously flawed way to predict ultimate behaviour. It is worth noting that principally because of the anxiogenic nature of these results, a small percentage of those interviewed did not wish to 
know about these SF [Oberg et al., 2015, Table 2]. In this context, it is necessary to explore the preferences of the patients and to obtain their consent. To this end, the search for SF must be explained clearly to patients to ensure that they have understood what SF are and what the implications and repercussions of finding them could be [Hehir-Kwa et al., 2015]. Depending on the analysis circuit, it could take a long time to obtain the results for WES and WGS, which gives time to patients to change their mind. The solution proposed would be to develop computerised «dynamic consent» [Kaye et al., 2015], which can allow consent preferences to 'travel' with the patient. This, however, would be difficult to implement and could exclude persons in precarious situations. An alternative would be deferred consent for SF [Oberg et al., 2015]. When participants were interviewed about the content of this consent, they principally expected detailed consent forms indicating the possibilities of possible prevention for certain variants, the fact that there may be errors in the interpretation of certain variants, the possibility that certain results could have a negative psychological impact, the possibility that results could evolve with advances in scientific knowledge, and finally the possibility of limiting the adverse effects of certain drugs if pharmacogenetic variants are searched [Appelbaum et al., 2014].

It is important to note that managing these SF is time-consuming, in terms of both clinical time, as it takes additional time to explain SF during consultations with patients, and time for interpreting the results. Participants would like consultations to last as long as necessary, up to $2 \mathrm{~h}$, while geneticists consider that no more than $30 \mathrm{~min}$ should be spent on this pre-test phase (77\%) [Appelbaum et al., 2014].

In parallel of our initiative, another group reviewed the literature relating on SF but focused more on qualitative studies [Mackley et al., 2017]. Our methodology also focused on quantitative studies that permitted to collect high numbers of opinions, in parallel of qualitative studies. The limits of this review of the literature are principally related to the heterogeneity of the articles studied. Indeed, they were conducted on different populations, in different countries with different legislation on patients' rights and different cultures, and proposed different methodologies that cannot be combined. While the total numbers of people concerned with these articles appear impressive (around 15,000), it turns out that only slightly more than 1200 people were offered and chose to learn such findings, while the others were confronted to hypothetical situations. Some of the studies collected opinions regarding SF in a research context, whereas others focused on SF in a diagnostic context, with different obligations for researchers and clinicians. When analysing in subgroups, the number of articles/respondants diminished. Methodological rigour varied and this aspect was difficult to 
take into account in compiling and comparing results. The quality and the way information was delivered also differed as it was given by medical geneticists, specialist doctors or genetic counsellors or in some cases by an information sheet or even a brief explanation by telephone. One of the major concerns among scholars on this issue is whether patient/participant/public responses to the question of the return of secondary findings were well-informed, i.e., if respondents are taking into account the uncertain risk of developing the disease and limited available actions related to many of the findings that they say they want. The quote from an article by Cliff and coll. [Cliff et al., 2015], that "one person justified the choice of knowing the results, including for non-actionable SF, by saying that he wanted to be sure that he wouldn't be a burden for his loved ones" is indicative of the inflated perception of clinical utility that people assume secondary findings possess, probably leading to their broad acceptance. Results may also differ depending on the study populations, in patients with rare diseases or cancer, interviewing adult patients, children or parents of children, certain articles making no distinction between the three. Patients with cancer are expected to have different opinions about the value of additional information as compared to people with long standing chronic diseases or parents of children with rare diseases. The information provided to society at large is usually more succinct than that given to participants, who are often better informed about genetic aspects because of their disease. It seems also essential to distinguish between guidelines for tests in children and those in adults, even though the differences between the studies were not significant. The only study involving surveys with teenagers showed that $83 \%$ of those surveyed wanted to receive non-actionable SF, and $72 \%$ believed that the decision on whether to receive SF should be shared between parents and children [Hufnagel et al., 2016]. In another study, Sapp and coll. 2014 [Sapp et al., 2014] showed that 56\% of parents of children with various genetic diseases would prefer to leave the choice to their child once he/she had reached adulthood, in order to preserve their independence and freedom. The question of access to results for late-onset diseases in children is not resolved, and contrasts with the absence of any possibility to obtain a pre-symptomatic diagnosis in children if there is no direct benefit in childhood. Certain teams proposed getting in touch with the children again when they became adults, but the risk of losing contact in the intervening period is huge. When parents also undergo sequencing as part of the diagnostic investigations, the question of informing only the transmitting parent appears to be a good alternative to avoid lost opportunities for relatives.

In general, a clear definition of SF and the concept of actionability was lacking. This review of the literature showed that it is essential to distinguish between actionable and non- 
actionable genes when discussing SF. The notion of actionability, however, is sometimes vague as it can sometimes refer to actionability for patients themselves, and in other circumstances, the concept is widened to genetic counselling for the family. Unfortunately, half of the articles made no difference between actionable and non-actionable secondary findings. All articles written prior to 2013 could not make use of the ACMG definition of actionability [Green et al., 2013], and thus most of the time were based on examples. The percentage of healthcare professionals prepared to return non-actionable SF needs to be interpreted with care, as, in general, the positive responses only reflect the fact that they found the minimal list of actionable genes too restrictive. In 2013, Dorschner and coll. [Dorschner et al., 2013] increased the list of ACMG genes to return by 62 additional actionable genes. Other lists have also been proposed in the literature. These lists are reported as non-exhaustive, containing a minimal number of genes that can be revised by laboratories. Certain authors proposed to screen for pharmacogenetic variants that may be relevant in chronic diseases subject to more medical prescriptions; or to search for heterozygosity in the most frequent rare recessive diseases, which may be relevant in terms of information for parenthood projects, in families already highly affected by the disease and the resulting handicap. It is worth noting that one study investigated the perception of pharmacogenetic data. It also appeared that doctors were not particularly inclined to use these data: $52 \%$ of the doctors surveyed did not think they would use pharmacogenetic data in current practice if such data were available [St Sauver et al., 2016].

Globally, based to the literature, a consensus came to light regarding the return of SF when patients requested them in teams where clinicians and biologists have validated a procedure to allow such disclosures. However, the existing literature on SF should be taken with caution, since most articles lack a clear definition of SF and the concept of actionability, focused on different populations of respondents, propose different methodologies that cannot be combined, and above all, referred to hypothetical scenarios. Studies conducted by multidisciplinary teams involving patients with access to results are sadly lacking in particular in the medium term after the results have been given. Such studies would feed the debate and make it possible to measure the impact of such findings and their benefit-risk ratio.

ACKNOWLEDGEMENTS: The authors thank the Burgundy Regional Council through the plan d'actions régional pour l'innovation (PARI 2016) and the European Union through the PO FEDER-FSE Bourgogne 2014/2020 programs for their financial support for this project. 


\section{LEGENDS}

Figure 1: Data describing the demographic and geographical characteristics of the articles a - Number of articles per year of publication and by type of study.

b - Distribution of articles by continent.

Figure 2: Number of subjects according to the type of study and to the methodology

Table 1: Studies of opinions centred on patients, healthcare professionals and society, classified according to their methodology: quantitative, qualitative or mixed.

Table 2: Synthesis of percentages of favourable opinions for the overall return of SF according to their actionability and the diagnosis/research criterion, when the article gave such information. 


\section{REFERENCES}

Allyse, Megan, and Marsha Michie. "Not-so-Incidental Findings: The ACMG Recommendations on the Reporting of Incidental Findings in Clinical Whole Genome and Whole Exome Sequencing." Trends in Biotechnology 31, no. 8 (August 2013): 439-41. doi:10.1016/j.tibtech.2013.04.006.

Amendola, Laura M., Michael O. Dorschner, Peggy D. Robertson, Joseph S. Salama, Ragan Hart, Brian H. Shirts, Mitzi L. Murray, et al. "Actionable Exomic Incidental Findings in 6503 Participants: Challenges of Variant Classification." Genome Research 25, no. 3 (March 2015): 305-15. doi:10.1101/gr.183483.114.

Anastasova, Velizara, Alessandro Blasimme, Sophie Julia, and Anne Cambon-Thomsen. "Genomic Incidental Findings: Reducing the Burden to Be Fair.” The American Journal of Bioethics: AJOB 13, no. 2 (2013): 5254. doi:10.1080/15265161.2012.754066.

Appelbaum, Paul S., Cameron R. Waldman, Abby Fyer, Robert Klitzman, Erik Parens, Josue Martinez, W. Nicholson Price, and Wendy K. Chung. "Informed Consent for Return of Incidental Findings in Genomic Research." Genetics in Medicine: Official Journal of the American College of Medical Genetics 16, no. 5 (May 2014): 367-73. doi:10.1038/gim.2013.145.

Barajas, Miguel, and Lainie Friedman Ross. "Pediatric Professionals' Attitudes about Secondary Findings in Genomic Sequencing of Children." The Journal of Pediatrics 166, no. 5 (May 2015): 1276-1282.e7. doi:10.1016/j.jpeds.2015.01.032.

Bennette CS, Gallego CJ, Burke W, Jarvik GP, Veenstra DL. The cost-effectiveness of returning incidental findings from next-generation genomic sequencing. Genet Med. 2015 Jul;17(7):587-95.

Berg, Jonathan S., Ann Katherine M. Foreman, Julianne M. O’Daniel, Jessica K. Booker, Lacey Boshe, Timothy Carey, Kristy R. Crooks, et al. "A Semiquantitative Metric for Evaluating Clinical Actionability of Incidental or Secondary Findings from Genome-Scale Sequencing." Genetics in Medicine: Official Journal of the American College of Medical Genetics 18, no. 5 (May 2016): 467-75. doi:10.1038/gim.2015.104.

Bowdin, Sarah, Adel Gilbert, Emma Bedoukian, Christopher Carew, Margaret P. Adam, John Belmont, Barbara Bernhardt, et al. "Recommendations for the Integration of Genomics into Clinical Practice." Genetics in Medicine: Official Journal of the American College of Medical Genetics, May 12, 2016. doi:10.1038/gim.2016.17.

Christenhusz, Gabrielle M., Koenraad Devriendt, Hilde Van Esch, and Kris Dierickx. "Focus Group Discussions on Secondary Variants and next-Generation Sequencing Technologies." European Journal of Medical Genetics 58, no. 4 (April 2015): 249-57. doi:10.1016/j.ejmg.2015.01.007.

Clift, Kristin E., Colin M. E. Halverson, Alexander S. Fiksdal, Ashok Kumbamu, Richard R. Sharp, and Jennifer B. McCormick. "Patients' Views on Incidental Findings from Clinical Exome Sequencing." Applied \& Translational Genomics 4 (March 2015): 38-43. doi:10.1016/j.atg.2015.02.005.

Daack-Hirsch, S., M. Driessnack, A. Hanish, V. A. Johnson, L. L. Shah, C. M. Simon, and J. K. Williams. “'Information Is Information': a Public Perspective on Incidental Findings in Clinical and Research Genome-Based Testing." Clinical Genetics 84, no. 1 (July 2013): 11-18. doi:10.1111/cge.12167.

De Ligt, Joep, Marjolein H. Willemsen, Bregje W. M. van Bon, Tjitske Kleefstra, Helger G. Yntema, Thessa Kroes, Anneke T. Vulto-van Silfhout, et al. "Diagnostic Exome Sequencing in Persons with Severe Intellectual Disability.” The New England Journal of Medicine 367, no. 20 (November 15, 2012): 1921-29. doi:10.1056/NEJMoa1206524.

Dorschner, Michael O., Laura M. Amendola, Emily H. Turner, Peggy D. Robertson, Brian H. Shirts, Carlos J. Gallego, Robin L. Bennett, et al. "Actionable, Pathogenic Incidental Findings in 1,000 Participants' Exomes.” American Journal of Human Genetics 93, no. 4 (October 3, 2013): 631-40. doi:10.1016/j.ajhg.2013.08.006. 
Downing, Nancy R., Janet K. Williams, Sandra Daack-Hirsch, Martha Driessnack, and Christian M. Simon. "Genetics Specialists' Perspectives on Disclosure of Genomic Incidental Findings in the Clinical Setting." Patient Education and Counseling 90, no. 1 (January 2013): 133-38. doi:10.1016/j.pec.2012.09.010.

Dressler, Lynn G., Sondra Smolek, Roselle Ponsaran, Janell M. Markey, Helene Starks, Nancy Gerson, Susan Lewis, et al. "IRB Perspectives on the Return of Individual Results from Genomic Research." Genetics in Medicine: Official Journal of the American College of Medical Genetics 14, no. 2 (February 2012): 215-22. doi:10.1038/gim.2011.10.

El, Carla G. van, Martina C. Cornel, Pascal Borry, Ros J. Hastings, Florence Fellmann, Shirley V. Hodgson, Heidi C. Howard, et al. "Whole-Genome Sequencing in Health Care: Recommendations of the European Society of Human Genetics.” European Journal of Human Genetics: EJHG 21, no. 6 (June 2013): 580-84. doi:10.1038/ejhg.2013.46.

Fernandez CV, Strahlendorf C, Avard D, Knoppers BM, O’Connell C, Bouffet E, et al. Attitudes of Canadian researchers toward the return to participants of incidental and targeted genomic findings obtained in a pediatric research setting. Genet Med. 2013 Jul;15(7):558-64.

Fernandez, Conrad V., Colleen O’Connell, Meghan Ferguson, Andrew C. Orr, Johane M. Robitaille, Bartha M. Knoppers, and Christopher R. McMaster. "Stability of Attitudes to the Ethical Issues Raised by the Return of Incidental Genomic Research Findings in Children: A Follow-Up Study." Public Health Genomics 18, no. 5 (2015): 299-308. doi:10.1159/000439244.

Fernandez, Conrad V., Eric Bouffet, David Malkin, Nada Jabado, Colleen O’Connell, Denise Avard, Bartha M. Knoppers, et al. "Attitudes of Parents toward the Return of Targeted and Incidental Genomic Research Findings in Children." Genetics in Medicine: Official Journal of the American College of Medical Genetics 16, no. 8 (August 2014): 633-40. doi:10.1038/gim.2013.201.

Fleming, J., C. Critchley, M. Otlowski, C. Stewart, and I. Kerridge. "Attitudes of the General Public towards the Disclosure of Individual Research Results and Incidental Findings from Biobank Genomic Research in Australia.” Internal Medicine Journal 45, no. 12 (December 2015): 1274-79. doi:10.1111/imj.12911.

Gilissen, Christian, Jayne Y. Hehir-Kwa, Djie Tjwan Thung, Maartje van de Vorst, Bregje W. M. van Bon, Marjolein H. Willemsen, Michael Kwint, et al. "Genome Sequencing Identifies Major Causes of Severe Intellectual Disability.” Nature 511, no. 7509 (July 17, 2014): 344-47. doi:10.1038/nature13394.

Gliwa, Catherine, Ilana R. Yurkiewicz, Lisa Soleymani Lehmann, Sara Chandros Hull, Nathan Jones, and Benjamin E. Berkman. "Institutional Review Board Perspectives on Obligations to Disclose Genetic Incidental Findings to Research Participants." Genetics in Medicine: Official Journal of the American College of Medical Genetics 18, no. 7 (July 2016): 705-11. doi:10.1038/gim.2015.149.

Gray, Stacy W., Elyse R. Park, Julie Najita, Yolanda Martins, Lara Traeger, Elizabeth Bair, Joshua Gagne, et al. 'Oncologists' and Cancer Patients' Views on Whole-Exome Sequencing and Incidental Findings: Results from The CanSeq Study." Genetics in Medicine : Official Journal of the American College of Medical Genetics, February 11, 2016. doi:10.1038/gim.2015.207.

Gray, Stacy W., Katherine Hicks-Courant, Christopher S. Lathan, Levi Garraway, Elyse R. Park, and Jane C. Weeks. "Attitudes of Patients with Cancer about Personalized Medicine and Somatic Genetic Testing." Journal of Oncology Practice / American Society of Clinical Oncology 8, no. 6 (November 2012): 329-335, 2 p following 335. doi:10.1200/JOP.2012.000626.

Green, Robert C., Jonathan S. Berg, Wayne W. Grody, Sarah S. Kalia, Bruce R. Korf, Christa L. Martin, Amy L. McGuire, et al. "ACMG Recommendations for Reporting of Incidental Findings in Clinical Exome and Genome Sequencing." Genetics in Medicine: Official Journal of the American College of Medical Genetics 15, no. 7 (July 2013): 565-74. doi:10.1038/gim.2013.73.

Grove ME, Wolpert MN, Cho MK, Lee SS-J, Ormond KE. Views of genetics health professionals on the return of genomic results. J Genet Couns. 2014 Aug;23(4):531-8. 
Haga, Susanne B., Genevieve Tindall, and Julianne M. O’Daniel. "Public Perspectives about Pharmacogenetic Testing and Managing Ancillary Findings." Genetic Testing and Molecular Biomarkers 16, no. 3 (March 2012): 193-97. doi:10.1089/gtmb.2011.0118.

Hehir-Kwa, Jayne Y., Mireille Claustres, Ros J. Hastings, Conny van Ravenswaaij-Arts, Gabrielle Christenhusz, Maurizio Genuardi, Béla Melegh, et al. "Towards a European Consensus for Reporting Incidental Findings during Clinical NGS Testing.” European Journal of Human Genetics: EJHG 23, no. 12 (December 2015): 1601-6. doi:10.1038/ejhg.2015.111.

Hitch, Kelly, Galen Joseph, Jenna Guiltinan, Jessica Kianmahd, Janey Youngblom, and Amie Blanco. "Lynch Syndrome Patients' Views of and Preferences for Return of Results Following Whole Exome Sequencing." Journal of Genetic Counseling 23, no. 4 (August 2014): 539-51. doi:10.1007/s10897-014-9687-6.

Hufnagel, Sophia B., Lisa J. Martin, Amy Cassedy, Robert J. Hopkin, and Armand H. Matheny Antommaria. “Adolescents' Preferences Regarding Disclosure of Incidental Findings in Genomic Sequencing That Are Not Medically Actionable in Childhood." American Journal of Medical Genetics. Part A 170, no. 8 (August 2016): 2083-88. doi:10.1002/ajmg.a.37730.

Hunter, Jessica Ezzell, Stephanie A. Irving, Leslie G. Biesecker, Adam Buchanan, Brian Jensen, Kristy Lee, Christa Lese Martin, et al. "A Standardized, Evidence-Based Protocol to Assess Clinical Actionability of Genetic Disorders Associated with Genomic Variation." Genetics in Medicine: Official Journal of the American College of Medical Genetics, April 28, 2016. doi:10.1038/gim.2016.40.

Jelsig AM, Qvist N, Brusgaard K, Ousager LB. Research participants in NGS studies want to know about incidental findings. Eur J Hum Genet. 2015 Oct;23(10):1423-6.

Kalia, Sarah S., Kathy Adelman, Sherri J. Bale, Wendy K. Chung, Christine Eng, James P. Evans, Gail E. Herman, et al. "Recommendations for Reporting of Secondary Findings in Clinical Exome and Genome Sequencing, 2016 Update (ACMG SF v2.0): A Policy Statement of the American College of Medical Genetics and Genomics." Genetics in Medicine: Official Journal of the American College of Medical Genetics 19, no. 2 (February 2017): 249-55. doi:10.1038/gim.2016.190.

Kaphingst KA, Ivanovich J, Biesecker BB, Dresser R, Seo J, Dressler LG, et al. Preferences for return of incidental findings from genome sequencing among women diagnosed with breast cancer at a young age. Clin Genet. 2016 Mar;89(3):378-84.

Kaye, Jane, Edgar A Whitley, David Lund, Michael Morrison, Harriet Teare, and Karen Melham. "Dynamic Consent: A Patient Interface for Twenty-First Century Research Networks.” European Journal of Human Genetics 23, no. 2 (February 2015): 141-46. doi:10.1038/ejhg.2014.71.

Keogh, Louise A., Douglass Fisher, Sherri Sheinfeld Gorin, Sheri D. Schully, Jan T. Lowery, Dennis J. Ahnen, Judith A. Maskiell, et al. "How Do Researchers Manage Genetic Results in Practice? The Experience of the Multinational Colon Cancer Family Registry." Journal of Community Genetics 5, no. 2 (April 2014): 99108. doi:10.1007/s12687-013-0148-y.

Kleiderman, E., D. Avard, A. Besso, S. Ali-Khan, G. Sauvageau, and J. Hébert. "Disclosure of Incidental Findings in Cancer Genomic Research: Investigators' Perceptions on Obligations and Barriers." Clinical Genetics 88, no. 4 (October 2015): 320-26. doi:10.1111/cge.12540.

Kleiderman, Erika, Bartha Maria Knoppers, Conrad V. Fernandez, Kym M. Boycott, Gail Ouellette, Durhane WongRieger, Shelin Adam, Julie Richer, and Denise Avard. "Returning Incidental Findings from Genetic Research to Children: Views of Parents of Children Affected by Rare Diseases." Journal of Medical Ethics 40, no. 10 (October 2014): 691-96. doi:10.1136/medethics-2013-101648.

Klitzman R, Appelbaum PS, Fyer A, Martinez J, Buquez B, Wynn J, et al. Researchers' views on return of incidental genomic research results: qualitative and quantitative findings. Genet Med. 2013 Nov;15(11):888-95.

Lee, Elizabeth M. J., Karen Xu, Emma Mosbrook, Amanda Links, Jessica Guzman, David R. Adams, Elise Flynn, et al. "Pharmacogenomic Incidental Findings in 308 Families: The NIH Undiagnosed Diseases Program 
Experience." Genetics in Medicine: Official Journal of the American College of Medical Genetics, June 2, 2016. doi:10.1038/gim.2016.47.

Lemke AA, Bick D, Dimmock D, Simpson P, Veith R. Perspectives of clinical genetics professionals toward genome sequencing and incidental findings: a survey study. Clin Genet. 2013 Sep;84(3):230-6.

Lohn, Zoe, Shelin Adam, Patricia Birch, Anne Townsend, and Jan Friedman. “Genetics Professionals' Perspectives on Reporting Incidental Findings from Clinical Genome-Wide Sequencing." American Journal of Medical Genetics. Part A 161A, no. 3 (March 2013): 542-49. doi:10.1002/ajmg.a.35794.

Lyon, Gholson J., Tao Jiang, Richard Van Wijk, Wei Wang, Paul Mark Bodily, Jinchuan Xing, Lifeng Tian, et al. "Exome Sequencing and Unrelated Findings in the Context of Complex Disease Research: Ethical and Clinical Implications.” Discovery Medicine 12, no. 62 (July 2011): 41-55.

Mackley MP, Fletcher B, Parker M, Watkins H, Ormondroyd E. Stakeholder views on secondary findings in wholegenome and whole-exome sequencing: a systematic review of quantitative and qualitative studies. Genet Med. 2017;19(3):283-93.

Manolio TA, Chisholm RL, Ozenberger B, Roden DM, Williams MS, Wilson R, Bick D, Bottinger EP, Brilliant MH, Eng C, Frazer KA, Korf B, Ledbetter DH, Lupski JR, Marsh C, Mrazek D, Murray MF, O'Donnell PH, Rader DJ, Relling MV, Shuldiner AR, Valle D, Weinshilboum R, Green ED, Ginsburg GS. Implementing genomic medicine in the clinic: the future is here. Genet Med. 2013 Apr;15(4):258-67.

Matthijs, Gert, Erika Souche, Mariëlle Alders, Anniek Corveleyn, Sebastian Eck, Ilse Feenstra, Valérie Race, et al. "Guidelines for Diagnostic next-Generation Sequencing." European Journal of Human Genetics: EJHG 24, no. 1 (January 2016): 2-5. doi:10.1038/ejhg.2015.226.

Meacham, Meredith C., Helene Starks, Wylie Burke, and Kelly Edwards. "Researcher Perspectives on Disclosure of Incidental Findings in Genetic Research." Journal of Empirical Research on Human Research Ethics: JERHRE 5, no. 3 (September 2010): 31-41. doi:10.1525/jer.2010.5.3.31.

Middleton, Anna, Katherine I. Morley, Eugene Bragin, Helen V. Firth, Matthew E. Hurles, Caroline F. Wright, Michael Parker, and DDD study. "Attitudes of Nearly 7000 Health Professionals, Genomic Researchers and Publics toward the Return of Incidental Results from Sequencing Research.” European Journal of Human Genetics: EJHG 24, no. 1 (January 2016): 21-29. doi:10.1038/ejhg.2015.58.

Oberg, Jennifer A., Julia L. Glade Bender, Elizabeth G. Cohn, Marilyn Morris, Jenny Ruiz, Wendy K. Chung, Paul S. Appelbaum, Andrew L. Kung, and Jennifer M. Levine. "Overcoming Challenges to Meaningful Informed Consent for Whole Genome Sequencing in Pediatric Cancer Research.” Pediatric Blood \& Cancer 62, no. 8 (August 2015): 1374-80. doi:10.1002/pbc.25520.

Parker, Lisa S. “The Future of Incidental Findings: Should They Be Viewed as Benefits?” The Journal of Law, Medicine \& Ethics: A Journal of the American Society of Law, Medicine \& Ethics 36, no. 2 (2008): 34151, 213. doi:10.1111/j.1748-720X.2008.00278.x.

Regier, Dean A., Stuart J. Peacock, Reka Pataky, Kimberly van der Hoek, Gail P. Jarvik, Jeffrey Hoch, and David Veenstra. "Societal Preferences for the Return of Incidental Findings from Clinical Genomic Sequencing: A Discrete-Choice Experiment." CMAJ: Canadian Medical Association Journal = Journal de l'Association Medicale Canadienne 187, no. 6 (April 7, 2015): E190-197. doi:10.1503/cmaj.140697.

Retterer, Kyle, Jane Juusola, Megan T. Cho, Patrik Vitazka, Francisca Millan, Federica Gibellini, Annette VertinoBell, et al. "Clinical Application of Whole-Exome Sequencing across Clinical Indications." Genetics in Medicine: Official Journal of the American College of Medical Genetics 18, no. 7 (July 2016): 696-704. doi:10.1038/gim.2015.148.

Sapp, J. C., D. Dong, C. Stark, L. E. Ivey, G. Hooker, L. G. Biesecker, and B. B. Biesecker. "Parental Attitudes, Values, and Beliefs toward the Return of Results from Exome Sequencing in Children." Clinical Genetics 85, no. 2 (February 2014): 120-26. doi:10.1111/cge.12254. 
Scheuner MT, Peredo J, Benkendorf J, Bowdish B, Feldman G, Fleisher L, et al. Reporting genomic secondary findings: ACMG members weigh in. Genet Med. 2015 Jan;17(1):27-35.

Shahmirzadi, Layla, Elizabeth C. Chao, Erika Palmaer, Melissa C. Parra, Sha Tang, and Kelly D. Farwell Gonzalez. "Patient Decisions for Disclosure of Secondary Findings among the First 200 Individuals Undergoing Clinical Diagnostic Exome Sequencing." Genetics in Medicine: Official Journal of the American College of Medical Genetics 16, no. 5 (May 2014): 395-99. doi:10.1038/gim.2013.153.

Simon, Christian M., Janet K. Williams, Laura Shinkunas, Debra Brandt, Sandra Daack-Hirsch, and Martha Driessnack. "Informed Consent and Genomic Incidental Findings: IRB Chair Perspectives." Journal of Empirical Research on Human Research Ethics: JERHRE 6, no. 4 (December 2011): 53-67. doi:10.1525/jer.2011.6.4.53.

St Sauver, Jennifer L., Suzette J. Bielinski, Janet E. Olson, Elizabeth J. Bell, Michaela E. Mc Gree, Debra J. Jacobson, Jennifer B. McCormick, et al. "Integrating Pharmacogenomics into Clinical Practice: Promise vs Reality." The American Journal of Medicine 129, no. 10 (October 2016): 1093-1099.e1. doi:10.1016/j.amjmed.2016.04.009.

Strong, K. A., K. L. Zusevics, D. Bick, and R. Veith. "Views of Primary Care Providers Regarding the Return of Genome Sequencing Incidental Findings.” Clinical Genetics 86, no. 5 (November 2014): 461-68. doi:10.1111/cge.12390.

Strong, Kimberly A., Kaija L. Zusevics, David P. Bick, and Regan Veith. "Views of Nonmedical, Health System Professionals Regarding the Return of Whole Genome Sequencing Incidental Findings." WMJ: Official Publication of the State Medical Society of Wisconsin 113, no. 5 (October 2014): 179-84.

Townsend, Anne, Shelin Adam, Patricia H. Birch, Zoe Lohn, Francois Rousseau, and Jan M. Friedman. "'I Want to Know What's in Pandora's Box': Comparing Stakeholder Perspectives on Incidental Findings in Clinical Whole Genomic Sequencing." American Journal of Medical Genetics. Part A 158A, no. 10 (October 2012): 2519-25. doi:10.1002/ajmg.a.35554.

Turbitt, Erin, Michelle M. Wiest, Jane L. Halliday, David J. Amor, and Sylvia A. Metcalfe. "Availability of Treatment Drives Decisions of Genetic Health Professionals about Disclosure of Incidental Findings." European Journal of Human Genetics: EJHG 22, no. 10 (October 2014): 1225-28. doi:10.1038/ejhg.2014.11.

Wynn, Julia, Josue Martinez, Jimmy Duong, Yuan Zhang, Jo Phelan, Abby Fyer, Robert Klitzman, Paul S. Appelbaum, and Wendy K. Chung. "Association of Researcher Characteristics with Views on Return of Incidental Findings from Genomic Research.” Journal of Genetic Counseling 24, no. 5 (October 2015): 833-41. doi:10.1007/s10897-014-9817-1.

Yang, Yaping, Donna M. Muzny, Fan Xia, Zhiyv Niu, Richard Person, Yan Ding, Patricia Ward, et al. "Molecular Findings among Patients Referred for Clinical Whole-Exome Sequencing." JAMA 312, no. 18 (November 12, 2014): 1870-79. doi:10.1001/jama.2014.14601.

Yang, Yaping, Donna M. Muzny, Jeffrey G. Reid, Matthew N. Bainbridge, Alecia Willis, Patricia A. Ward, Alicia Braxton, et al. "Clinical Whole-Exome Sequencing for the Diagnosis of Mendelian Disorders." The New England Journal of Medicine 369, no. 16 (October 17, 2013): 1502-11. doi:10.1056/NEJMoa1306555.

Yu, Joon-Ho, Tanya M. Harrell, Seema M. Jamal, Holly K. Tabor, and Michael J. Bamshad. “Attitudes of Genetics Professionals toward the Return of Incidental Results from Exome and Whole-Genome Sequencing." American Journal of Human Genetics 95, no. 1 (July 3, 2014): 77-84. doi:10.1016/j.ajhg.2014.06.004. 
Figure 1a

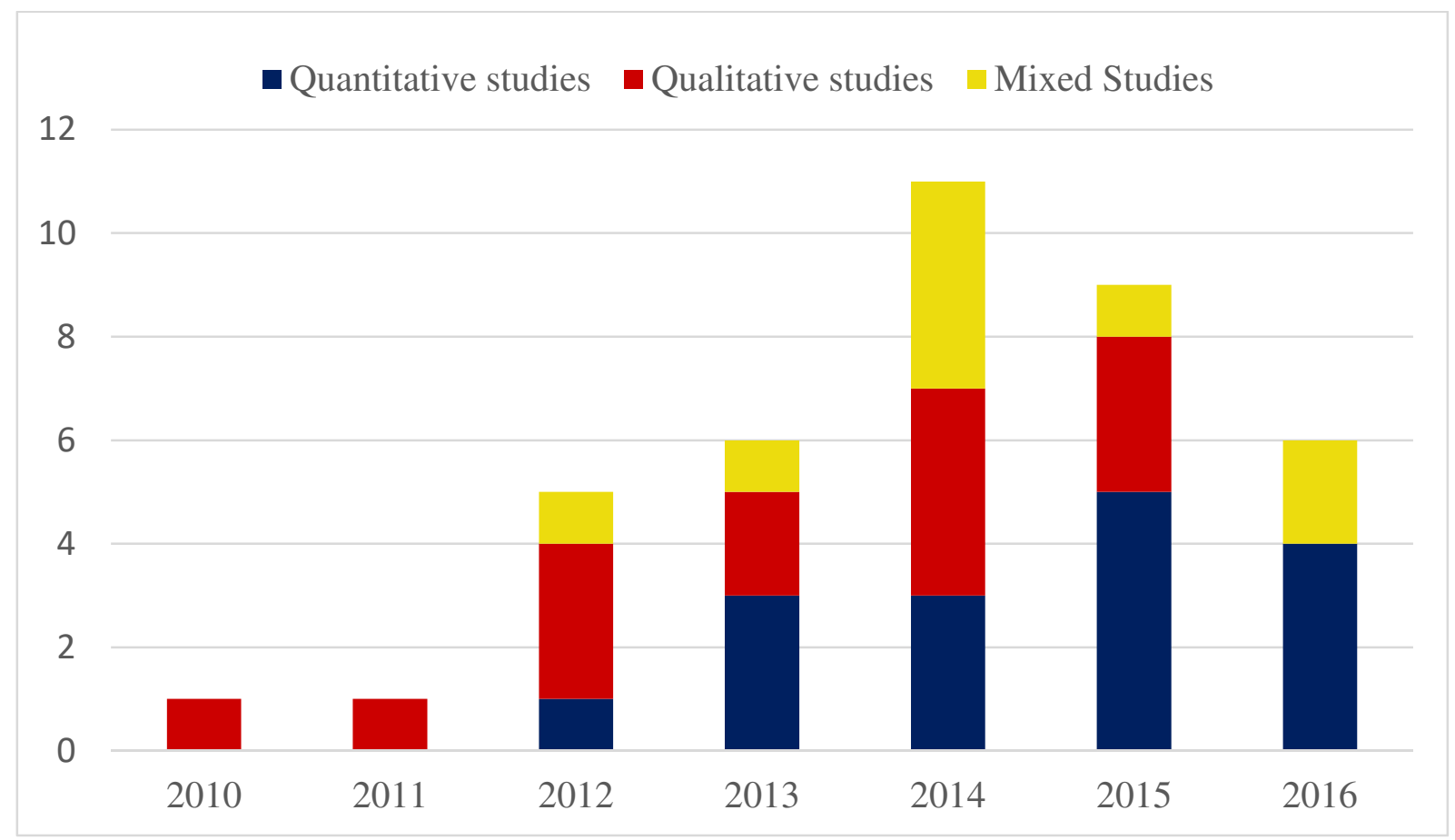

Figure 1b

- North America - Europe $\quad$ Australia

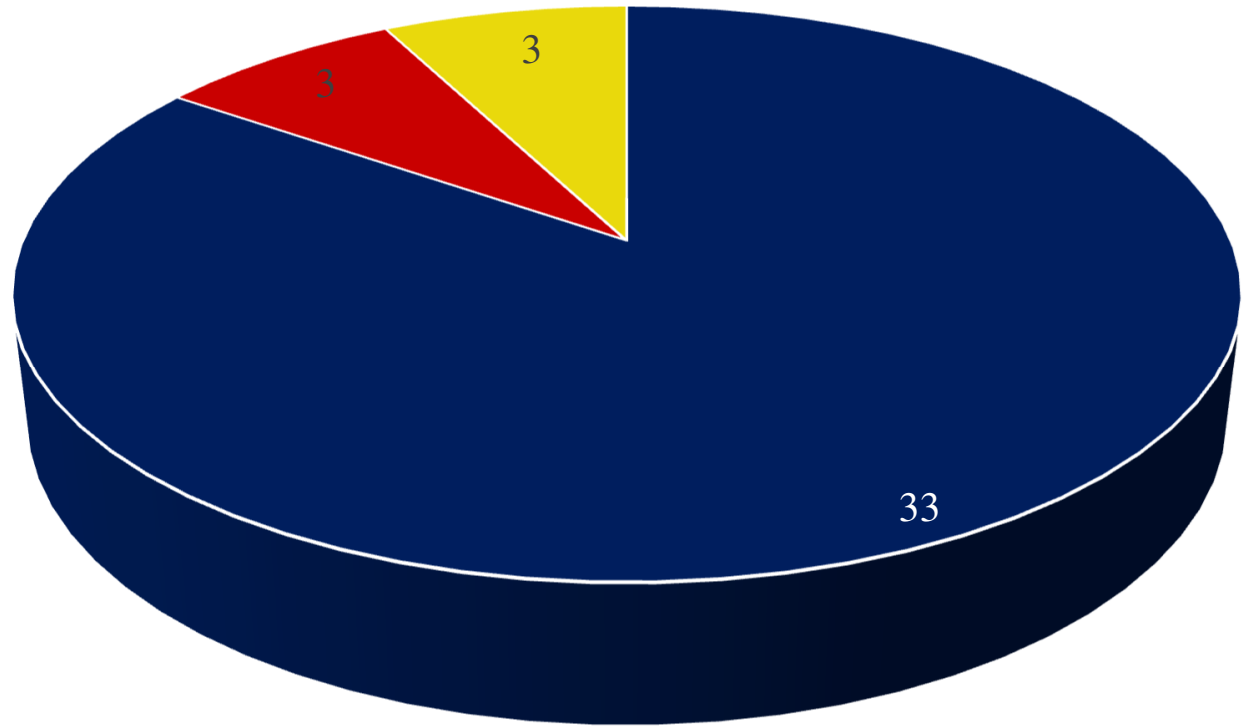


Figure 2

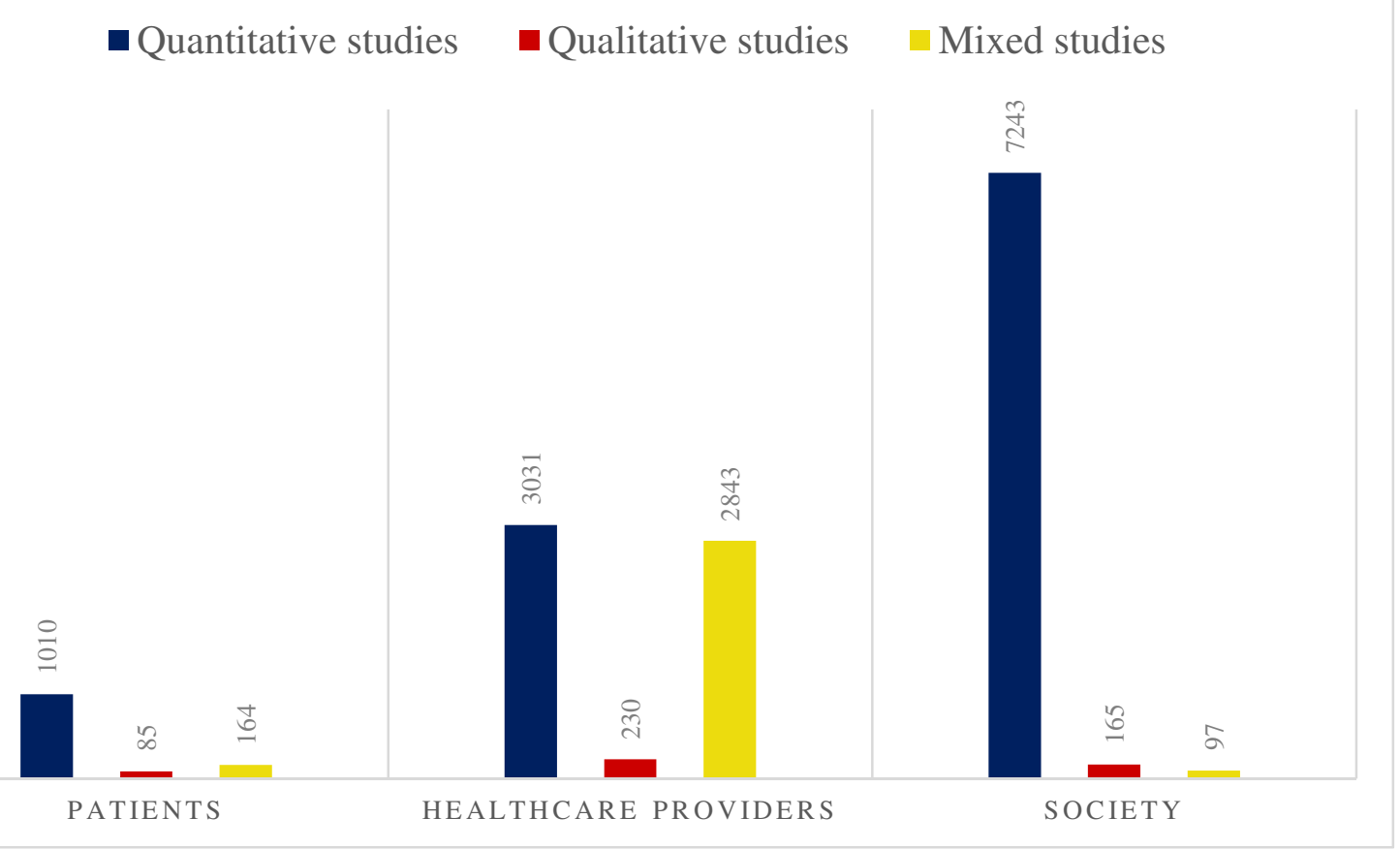


Table 1a: Studies of opinions centred on patients and classified according to their methodology: quantitative, qualitative or mixed (quantitative + qualitative).

\begin{tabular}{|c|c|c|c|}
\hline $\begin{array}{l}\text { Author / Year } \\
\text { of publication }\end{array}$ & Title & Number of subjects studied/Method & Main result \\
\hline \multicolumn{4}{|c|}{ Quantitative methodology } \\
\hline $\begin{array}{l}\text { Shahmirzadi et } \\
\text { al., } 2013\end{array}$ & $\begin{array}{l}\text { Patient decisions for disclosure } \\
\text { of secondary findings among the } \\
\text { first } 200 \text { individuals undergoing } \\
\text { clinical diagnostic exome } \\
\text { sequencing }\end{array}$ & $\begin{array}{l}\text { Exome sequencing: diagnosis } \\
200 \text { retrospective analyses of the choices of patients } \\
\text { for the return of secondary findings classified in } 4 \\
\text { categories, } 162 \text { parents of affected children (mean } \\
\text { age } 5 \text { years), } 38 \text { affected adults (mean age } 38 \text { years). } \\
\text { All types of genetic diseases }\end{array}$ & $\begin{array}{l}94 \% \text { of patients chose to receive information on actionable secondary findings proposed ( } 92 \% \text { for carrier } \\
\text { status in recessive diseases, } 89 \% \text { for the actionable genes with a predisposition for cancer, } 92 \% \text { for genes } \\
\text { with an actionable predisposition for adult-onset diseases, } 95 \% \text { for genes with an actionable } \\
\text { predisposition to early-onset diseases). } \\
\text { Parents of affected children were more likely to want to receive secondary findings for their child (96\%, } \\
155 / 162 \text { ) than were affected adults for themselves }(32 / 38,84 \%)\end{array}$ \\
\hline $\begin{array}{l}\text { Fernandez et } \\
\text { al., } 2014\end{array}$ & $\begin{array}{l}\text { Attitudes of parents toward the } \\
\text { return of targeted and incidental } \\
\text { genomic research findings in } \\
\text { children }\end{array}$ & $\begin{array}{l}\text { Exome sequencing: research } \\
362 \text { respondents, } 86 \text { parents of children with cancer, } \\
276 \text { parents of children presenting rare diseases } \\
87 \% \text { of parents interviewed were more than } 35 \text { years } \\
\text { old } \\
36 \text {-item questionnaire }\end{array}$ & $\begin{array}{l}86 \% \text { wished to receive results for secondary findings, with no difference between patients with cancer } \\
\text { and those with rare diseases, and } 92 \% \text { wanted the results to include predispositions to child-onset diseases } \\
\text { (97\% if there was possible treatment or prevention, } 83 \% \text { otherwise). } 83 \% \text { wanted to be informed about } \\
\text { secondary findings even if they concerned untreatable and fatal diseases; } 70 \% \text { wanted to be informed for } \\
\text { variants of unknown significance. } 93 \% \text { of those interviewed believed that their at-risk relatives should be } \\
\text { informed about their risk in cases of a serious treatable disease, and } 88 \% \text { in cases of an untreatable disease. } \\
74 \% \text { believed that the results returned after the death of a patient should be disclosed. }\end{array}$ \\
\hline $\begin{array}{l}\text { Fernandez et } \\
\text { al., } 2015\end{array}$ & $\begin{array}{l}\text { Stability of Attitudes to the } \\
\text { Ethical Issues Raised by the } \\
\text { Return of Incidental Genomic } \\
\text { Research Findings in Children: A } \\
\text { Follow-Up Study }\end{array}$ & $\begin{array}{l}\text { Exome sequencing: research } \\
154 \text { parents of children with rare diseases already } \\
\text { interviewed } 18 \text { months earlier } \\
55.7 \% \text { were more than } 50 \text { years old } \\
\text { Survey then } 19 \text {-item questionnaire }\end{array}$ & $\begin{array}{l}\text { The responses were stable over time, } 85 \% \text { declared that they had the right to receive secondary findings } \\
\text { discovered through research even for predispositions for incurable diseases. } 74 \% \text { believed that the results } \\
\text { must be shared with at-risk members of the family. }\end{array}$ \\
\hline $\begin{array}{l}\text { Jelsig et al., } \\
2015\end{array}$ & $\begin{array}{l}\text { Research participants in NGS } \\
\text { studies want to know about } \\
\text { incidental findings }\end{array}$ & $\begin{array}{l}127 \text { participants in a study proposing WES for } \\
\text { research in a context of gastrointestinal polyps }\end{array}$ & $\begin{array}{l}\text { Participants were given three choices: } \\
\begin{aligned}- & 61 \% \text { (78) wanted the disclosure of all incidental findings } \\
- & 36 \% \text { (45) wanted the disclosure of actionable incidental findings only } \\
- & 3 \% \text { (4) did not want any incidental findings at all. }\end{aligned}\end{array}$ \\
\hline
\end{tabular}




\begin{tabular}{|c|c|c|c|}
\hline $\begin{array}{l}\text { Gray et al., } \\
2016\end{array}$ & $\begin{array}{l}\text { Oncologists' and Cancer Patients' } \\
\text { Views on Whole-Exome } \\
\text { Sequencing and Incidental } \\
\text { Findings: Results from The } \\
\text { CanSeq } \\
\text { Study }\end{array}$ & $\begin{array}{l}\text { Exome sequencing: research and transfer } \\
\mathbf{1 6 7} \text { patients presenting stage IV lung or } \\
\text { colorectal adenocarcinoma } \\
\text { Mean age } 59.8 \text { years } \\
\text { ( } 27 \text { oncologists) } \\
\text { Prospective study with surveys }\end{array}$ & $\begin{array}{l}\text { The vast majority of patients }(\geq 95 \%) \text { wanted to know actionable secondary findings whether or not they } \\
\text { were related to the disease. } 85 \% \text { of patients also wanted to be informed about predispositions to non- } \\
\text { actionable diseases. } 99 \% \text { of the respondents were interested to find out about pharmacogenetic data } \\
\text { relative to their cancer and } 96 \% \text { wished to know about pharmacogenetic data not related to the cancer. }\end{array}$ \\
\hline \multicolumn{4}{|c|}{ Qualitative methodology } \\
\hline $\begin{array}{l}\text { Townsend } \\
\text { al., } 2012\end{array}$ & $\begin{array}{l}\text { "I Want to Know What's in } \\
\text { Pandora's Box": } \\
\text { Comparing Stakeholder } \\
\text { Perspectives on Incidental } \\
\text { Findings in Clinical Whole } \\
\text { Genomic Sequencing }\end{array}$ & $\begin{array}{l}\text { Exome sequencing: diagnosis } \\
10 \text { Doctors } \\
\mathbf{8} \text { Patients } \\
10 \text { persons representing society at large. } \\
\text { Debates following a guide, led by a moderator. }\end{array}$ & $\begin{array}{l}\text { The authors brought to light } 5 \text { themes relative to the return of secondary findings: } \\
\text { - } \\
\text { Pre-test information: all of the groups agreed that this step was crucial to give patients an } \\
\text { informed choice } \\
\text { The patient's choice: even if the healthcare professionals agreed with the principle of patient's } \\
\text { choice, they insisted on the fact that it was necessary to adapt what the patient wanted to know } \\
\text { to what the patient was able to understand. For patients, their choice should take precedence } \\
\text { of that of the healthcare professional. } \\
\text { - } \quad \text { Responsibility: patients and professionals agreed that it was up to the patient to contact the } \\
\text { clinician in cases of technological progress. } \\
\text { The return of secondary findings: the practitioners recognised that the return of these } \\
\text { secondary findings took time, and required empathy and expertise in genetics, making it } \\
\text { difficult for a non-specialist doctor to return the results. For patients and society at large, the } \\
\text { most important was neither experience nor expertise of the doctor, but his/her pedagogy in } \\
\text { providing explanations. } \\
\text { The impact and implications of secondary findings: the biggest problem for professionals was } \\
\text { the anxiety that disclosure of these findings could cause in patients. For the patients and } \\
\text { society at large, this anxiety should not be an obstacle to the return of secondary findings; it } \\
\text { was up to the patient alone to choose the data he/she wanted to receive and to judge the impact } \\
\text { that they would have on him/her. }\end{array}$ \\
\hline
\end{tabular}




\begin{tabular}{|c|c|c|c|}
\hline $\begin{array}{lll}\text { Sapp et al., } \\
2014\end{array}$ & $\begin{array}{l}\text { Parental attitudes, values, and } \\
\text { beliefs toward the return of } \\
\text { results from exome sequencing } \\
\text { in children }\end{array}$ & $\begin{array}{l}\text { Exome sequencing: research } \\
25 \text { parents of } 13 \text { child index cases with different } \\
\text { genetic diseases } \\
\text { Semi-structured Interviews by telephone. } \\
\text { Mean age } 39 \text { years (parents) index cases }(7.25 \\
\text { years) }\end{array}$ & $\begin{array}{l}\text { The majority of parents preferred to receive all types of result. They all wanted to receive the actionable } \\
\text { secondary findings to guide the medical management of their child, but also for the benefits that they } \\
\text { themselves could take advantage of. Concerning non-actionable data, } 15 \text { parents did not to receive these } \\
\text { findings or were reluctant. They expressed a need to think more about this option. The results concerning } \\
\text { recessive variants were more mixed; } 14 \text { parents preferred to leave the choice to their children when they } \\
\text { reached adulthood. }\end{array}$ \\
\hline $\begin{array}{l}\text { Kleiderman et } \\
\text { al., } 2014\end{array}$ & $\begin{array}{l}\text { Returning incidental findings } \\
\text { from genetic research to } \\
\text { children: views of parents of } \\
\text { children affected by rare } \\
\text { diseases. }\end{array}$ & $\begin{array}{l}\text { Exome sequencing: research } \\
\mathbf{1 5} \text { Parents of children with various rare genetic } \\
\text { diseases. } \\
2 \text { work groups of } 3 \text { persons each } \\
9 \text { interviews by telephone }\end{array}$ & $\begin{array}{l}\text { The parents appeared enthusiastic about the idea of receiving secondary findings concerning their } \\
\text { children. they underlined, however, } 4 \text { important points for them: } \\
\text { The right to information: meaning their right as parents to receive secondary findings concerning their } \\
\text { children } \\
\text { The benefit-risk ratio of knowing these secondary findings: all of the participants thought that knowing } \\
\text { these secondary findings would enable them to better plan the care for their child. } \\
\text { The way the results should be given: } \\
\text { Between the expert and the patient, they asked for true, clear and concise information from a doctor with } \\
\text { expertise in genetics. } \\
\text { Between them and their family: they agreed that it was up to them to explain the results to their child and } \\
\text { the majority thought it was their responsibility to tell their families about these results } \\
\text { The provision of « support » to accompany patients during the return of secondary findings: this could } \\
\text { be done by genetic counsellors, psychologists, support groups. They recognised that the Internet had } \\
\text { provided a lot of information but the majority of parents preferred to get information during consultations } \\
\text { with a clinician. }\end{array}$ \\
\hline Clift et al., 2015 & $\begin{array}{l}\text { Patients' views on incidental } \\
\text { findings from clinical exome } \\
\text { sequencing }\end{array}$ & $\begin{array}{l}\text { Exome sequencing: diagnosis } \\
37 \text { persons who underwent WES for a rare disease } \\
\text { or cancer } \\
55 \text { semi-structured interviews }\end{array}$ & $\begin{array}{l}\text { The interviews were conducted on } 4 \text { different occasions: before the before the first consultation with a } \\
\text { genetic counsellor, after the first consultation with a genetic counsellor, while waiting for the results, after } \\
\text { their return. } \\
\text { Diversity of opinions on the types of results to return, but consensus on the importance for the patients of } \\
\text { taking part in their choice. The majority thought that knowing the results for the secondary findings would } \\
\text { improve their quality of life and allow them to prevent or at least prepare for future diseases. }\end{array}$ \\
\hline
\end{tabular}




\begin{tabular}{|c|c|c|c|}
\hline $\begin{array}{lll}\text { Gray } & \text { et } & \text { al., } \\
2012 & & \end{array}$ & $\begin{array}{l}\text { Attitudes of Patients With } \\
\text { Cancer About Personalized } \\
\text { Medicine and Somatic Genetic } \\
\text { Testing }\end{array}$ & $\begin{array}{l}\text { Hypothetical situation } \\
69 \text { patients with colorectal, lung or breast cancer. } \\
\text { Median age } 59 \text { years ( } 32-86 \text { years) } \\
\text { Semi-structured interviews and binary-choice } \\
\text { questions }\end{array}$ & $81 \%$ would have wanted access to actionable SF, only $62 \%$ when the benefit was not clearly established. \\
\hline $\begin{array}{l}\text { Appelbaum et } \\
\text { al., } 2014\end{array}$ & $\begin{array}{l}\text { Informed Consent for Return of } \\
\text { Incidental Findings in Genomic } \\
\text { Research }\end{array}$ & $\begin{array}{l}\text { Exome sequencing: research } \\
20 \text { patients (mean age } 44 \text { years) who had } \\
\text { undergone WES participated in the study (semi- } \\
\text { structured interviews). } \\
254 \text { researchers in genetics, } 28 \text { genomic researchers } \\
\text { (semi-structured interviews) }\end{array}$ & $\begin{array}{l}\text { The aim of this study was to report the point of view of patients on the consent process and their } \\
\text { preferences with regard to the procedure. } \\
\text { This study identified the principal benefits related to the return of secondary findings. For patients: } \\
\text { - } 95 \%(19 / 20) \text { thought that a predisposition to a treatable disease could be identified } \\
\text { - } 95 \%(19 / 20) \text { thought that preventive measures could be implemented } \\
\text { - } \quad 85 \%(17 / 20) \text { thought that genetic counselling could be implemented for the descendants } \\
90 \%(18 / 20) \text { thought that the pharmacogenetic variants could make it possible to adapt } \\
\text { treatments for patients } \\
\text { The majority of patients thought that the consent for HTS should contain information on secondary } \\
\text { findings: the possible prevention for certain variants, the possibility to limit the adverse effects of certain } \\
\text { drugs for pharmacogenetic variants, the fact that there may have been errors in the interpretation of certain } \\
\text { variants, the possibility that certain results could have a negative psychological effect, the possibility of } \\
\text { evolution of results with advances in scientific knowledge. }\end{array}$ \\
\hline $\begin{array}{l}\text { Oberg et al., } \\
2015\end{array}$ & $\begin{array}{l}\text { Overcoming Challenges to } \\
\text { Meaningful Informed Consent } \\
\text { for Whole Genome } \\
\text { Sequencing in Pediatric Cancer } \\
\text { Research }\end{array}$ & $\begin{array}{l}15 \text { parents of children with cancer split into } 4 \text { groups } \\
\text { and semi-structured interviews in a control group of } \\
10 \text { patients without cancer to establish } \\
\text { recommendations for consent for genetic } \\
\text { investigations in children with cancer. }\end{array}$ & $\begin{array}{l}\text { The desire to receive secondary findings was high in all groups }(80 \%) \text {, but certain persons did not want } \\
\text { these results because they feared it would cause anxiety. All preferred consent in } 2 \text { steps, and giving } \\
\text { consent for secondary findings after a delay of two months. }\end{array}$ \\
\hline
\end{tabular}




\begin{tabular}{|c|c|c|c|}
\hline $\begin{array}{l}\text { Kaphingst et } \\
\text { al., } 2016\end{array}$ & $\begin{array}{l}\text { Preferences for Return of } \\
\text { Incidental Findings from } \\
\text { Genome Sequencing Among } \\
\text { Women Diagnosed with Breast } \\
\text { Cancer at a Young Age }\end{array}$ & $\begin{array}{l}60 \text { semi-structured interviewed of women } \\
\text { diagnosed with breast cancer at age } 40 \text { or younger. }\end{array}$ & 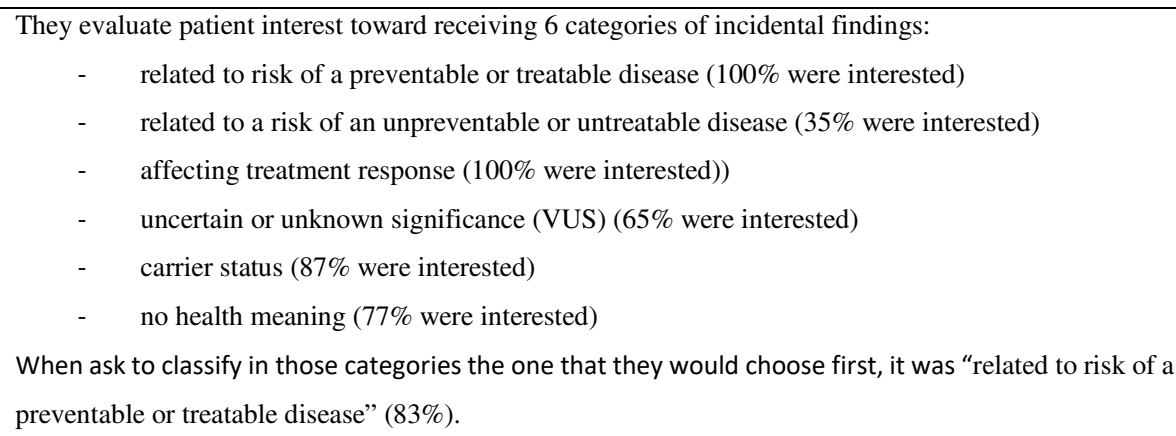 \\
\hline
\end{tabular}


Table 1b: Studies of opinions centred on healthcare professionals and classified according to the methodology used: quantitative, qualitative or mixed (quantitative + qualitative).

\begin{tabular}{|c|c|c|c|}
\hline $\begin{array}{l}\text { Author } \quad / \\
\text { Year of } \\
\text { publication }\end{array}$ & Title & Number of subjects studied/Method & Main result \\
\hline \multicolumn{4}{|c|}{ Quantitative methodology } \\
\hline $\begin{array}{l}\text { Lohn et al., } \\
2012\end{array}$ & $\begin{array}{l}\text { Genetics Professionals' Perspectives on Reporting } \\
\text { Incidental Findings From Clinical Genome-Wide } \\
\text { Sequencing }\end{array}$ & $\begin{array}{l}114 \text { geneticists and } 96 \text { genetic counsellors } \\
\text { Survey sent by email. }\end{array}$ & $\begin{array}{l}\text { If the HTS concerned an adult patient (Ad) or a child patient (Ch): } \\
\text { - } 94 \% \text { (Ad) and } 96 \%(\mathrm{Ch}) \text { were in favour of returning of variants } \\
\text { with a predisposition to serious diseases and accessible to } \\
\text { treatment } \\
\text { - } 75 \% \text { (Ad) and } 70 \% \text { (Ch) were in favour of returning of } \\
\text { pharmacogenetic variants } \\
\text { - } 57 \% \text { (Ad) and } 40 \%(\mathrm{Ch}) \text { were in favour of returning variants with } \\
\text { a predisposition to untreatable serious diseases } \\
\text { - } 73 \%(\text { Ad) and } 40 \%(\mathrm{Ch}) \text { were in favour of returning heterozygous } \\
\text { recessive variants } \\
29 \% \text { (Ad) and } 28 \%(\mathrm{Ch}) \text { were in favour of returning variants of } \\
\text { unknown significance }\end{array}$ \\
\hline $\begin{array}{l}\text { Fernandez et } \\
\text { al., } 2013\end{array}$ & $\begin{array}{l}\text { Attitudes of Canadian Researchers toward the return to } \\
\text { participants of incidental and targeted genomic findings } \\
\text { obtained in a pediatric research setting }\end{array}$ & $\begin{array}{l}74 \text { Researchers (Genomic researchers, medical } \\
\text { geneticists and nongeneticists clinicians) from the } \\
\text { Canadian Pediatric Cancer Genome Consortium } \\
\text { (CPCGC) and the } \\
\text { Finding of Rare Genes Canada Consortium } \\
\text { (FORGE) } \\
\text { Questionnaire sent by mail }\end{array}$ & $\begin{array}{l}\text { Only } 16 \% \text { of the researchers feel a strong responsibility to look for meaningful } \\
\text { incidental results. But if an incidental result was noted, } 78 \% \text { think they had an } \\
\text { obligation to transmit this result. Medical geneticists ( } 57 \% \text { ) were significantly } \\
\text { more likely than genomics researchers (18\%) to report a feeling of } \\
\text { responsibility to examine the data set for incidental clinically relevant } \\
\text { findings. }\end{array}$ \\
\hline
\end{tabular}




\begin{tabular}{|c|c|c|c|}
\hline $\begin{array}{l}\text { Lemke et al., } \\
2013\end{array}$ & $\begin{array}{l}\text { Perspectives of clinical genetics professionals toward genome } \\
\text { sequencing and incidental findings: A survey study }\end{array}$ & $\begin{array}{l}279 \text { clinical geneticist professional attendees of an } \\
\text { ACMG workshop. } \\
\text { Comparison of what they want to know and what } \\
\text { they want to disclose. }\end{array}$ & $\begin{array}{l}96 \% \text { wanted to know about incidental findings indicating a "clinically } \\
\text { actionable" adult-onset disease, } 78 \% \text { in their children (vs } 44 \% \text { and } 31 \% \text { for } \\
\text { non-actionable diseases) } \\
99 \% \text { wanted to know about child onset clinically actionable IF vs } 75 \% \text { for } \\
\text { non-actionable diseases. }\end{array}$ \\
\hline $\begin{array}{l}\text { Yu et al., } \\
2014\end{array}$ & $\begin{array}{l}\text { Attitudes of Genetics Professionals Toward the Return of } \\
\text { Incidental Results from Exome and Whole-Genome } \\
\text { Sequencing }\end{array}$ & $\begin{array}{l}760 \text { responses completed } \\
\text { Questionnaire with binary responses and open } \\
\text { questions } \\
\text { Aim: characterise the attitude of geneticists } \\
\text { concerning the return of results of WES and WGS, } \\
\text { their procedure to return results and their opinions } \\
\text { concerning the recommendations of the ACMG. }\end{array}$ & $\begin{array}{l}\text { Concerning secondary findings related to ACMG genes, these could be } \\
\text { returned to adult patients on request ( } 85 \%) \text {, to healthy adult relatives of an } \\
\text { index case ( } 75 \%) \text {, to parents of affected children ( } 74 \%) \text {. They thought they } \\
\text { should return data concerning adult-onset diseases }(62 \%) \text { and carrier status for } \\
\text { recessive genes ( } 62 \% \text { ) to parents of affected children. Half thought that they } \\
\text { should not restrict data to medically actionable findings. } 81 \% \text { thought that } \\
\text { individual preferences should guide the return of findings. }\end{array}$ \\
\hline $\begin{array}{l}\text { Scheuner et } \\
\text { al., } 2014\end{array}$ & $\begin{array}{l}\text { Reporting genomic secondary findings: ACMG members } \\
\text { weigh in }\end{array}$ & $\begin{array}{l}492 \text { members of ACMG. } \\
\text { Online survey }\end{array}$ & $\begin{array}{l}71.5 \% \text { supported the return of incidental findings from the } 56 \text { genes list of the } \\
\text { ACMG in adults and } 46.5 \% \text { in children. } 50.9 \% \text { thought that laboratories } \\
\text { should intentionally look at those IF in adult vs } 38.7 \% \text { in minors. } 37.6 \% \\
\text { thought that IF should be actively researched in unaffected parents of an } \\
\text { affected child. } 80.7 \% \text { thought that the patient should be allowed to opt out } \\
\text { receiving IF and even to choose which gene he will receive for } 46.2 \% \text {. The } \\
\text { exploratory analysis identified four factors that explained } 51 \% \text { of the survey } \\
\text { variance: best practices, patient preferences, guidance and informed consent. }\end{array}$ \\
\hline $\begin{array}{l}\text { Barajas and } \\
\text { Ross, } 2015\end{array}$ & $\begin{array}{l}\text { Pediatric Professionals' Attitudes about Secondary Findings in } \\
\text { Genomic Sequencing of Children }\end{array}$ & $\begin{array}{l}179 \text { members of the AAP (American Academy of } \\
\text { Pediatrics), of whom } 101 \text { were involved in the SOB } \\
\text { (Section Of Bioethics) and } 74 \text { in the SGBD } \\
\text { (Section of Genetics and Birth Defects), } 4 \text { were } \\
\text { involved in both groups and were excluded from } \\
\text { the comparative analyses. } \\
\text { Surveys sent by email and post. } \\
\text { Aim: examine the opinion of doctors with regard to } \\
\text { the recommendations of the ACMG }\end{array}$ & $\begin{array}{l}>80 \% \text { thought that the children and their parents had the right to choose to be } \\
\text { informed or not. } \\
35 \% \text { of members of the AAP and of the SOB supported the recommendations } \\
\text { of the ACMG compared with } 71 \% \text { for the SGBD. This difference can be } \\
\text { explained by the fact that the SOB is essentially against giving access to the } \\
\text { results for late-onset diseases affecting children. } \\
30 \% \text { of each group thought that the parents should not have access to data on } \\
\text { adult-onset diseases. } \\
\text { No consensus for reporting mutations if management would only benefit the } \\
\text { parents: } 34.5 \% \text { were in favour in the group AAP-SOB vs. } 80 \% \text { of members of } \\
\text { the SGBD. }\end{array}$ \\
\hline
\end{tabular}




\begin{tabular}{|c|c|c|c|}
\hline $\begin{array}{l}\text { Wynn et al., } \\
2015\end{array}$ & $\begin{array}{l}\text { Association of Researcher Characteristics with Views on } \\
\text { Return of Incidental Findings from Genomic Research }\end{array}$ & $\begin{array}{l}\text { Exome sequencing: research } \\
241 \text { included } \\
\text { Questionnaire with fixed-response questions and } \\
\text { opportunities to enter free-text comments. } \\
\text { Aim: see how the characteristics and the experience } \\
\text { of researchers were associated with their opinions } \\
\text { concerning secondary findings. }\end{array}$ & $\begin{array}{l}\text { Researchers with no clinical training, who did not provide care to patients, and } \\
\text { who were not involved in returning results were more likely to return } \\
\text { secondary findings to patients. Among the researchers who wished to return } \\
\text { secondary findings themselves, } 48 \% \text { of those with and } 58 \% \text { of those without } \\
\text { clinical training thought that it would be beneficial to return pharmacogenetic } \\
\text { data to patients; } 51 \% \text { of those with clinical training wanted to return high- } \\
\text { penetrance variants with no possible intervention, versus } 65 \% \text { for those } \\
\text { without clinical training; } 98 \% \text { of those with clinical training wanted to return } \\
\text { actionable high-penetrance variants, versus } 94 \% \text { for those without clinical } \\
\text { training. }\end{array}$ \\
\hline $\begin{array}{l}\text { Gliwa et al., } \\
2016\end{array}$ & $\begin{array}{l}\text { IRB (institutional review boards) perspectives on obligations } \\
\text { to disclose genetic incidental findings to research participants }\end{array}$ & $\begin{array}{l}\text { Exome sequencing: research } \\
796 \text { reviewers belonging to the group "Public } \\
\text { Responsibility in Medicine and Research" } \\
\text { Survey } \\
\text { Aim: study the opinions of research ethics } \\
\text { committees concerning the return of results and the } \\
\text { interpretation of secondary findings }\end{array}$ & $\begin{array}{l}74 \% \text { of respondents said they had had experience with secondary findings in } \\
\text { genetics, but only } 47 \% \text { felt ready to return secondary findings (actionable or } \\
\text { not). } 96 \% \text { recognised the right not to be informed. } 7 \% \text { thought that the time } \\
\text { and effort devoted to the analysis of these secondary findings was an obstacle } \\
\text { to the obligation to return SF to patients. }\end{array}$ \\
\hline \multicolumn{4}{|c|}{ Qualitative methodology } \\
\hline $\begin{array}{l}\text { Meacham et } \\
\text { al., } 2010\end{array}$ & $\begin{array}{l}\text { Researcher Perspectives on Disclosure of Incidental Findings } \\
\text { in Genetic Research }\end{array}$ & $\begin{array}{l}\text { Exome sequencing: research } \\
44 \text { researchers } \\
\text { Semi-structured telephone interviews } \\
\text { Aim: observe the responses of researchers to a } \\
\text { hypothetical discovery of data of unknown } \\
\text { significance following HTS for research purposes. }\end{array}$ & $\begin{array}{l}\text { The decision to return the data or not was based on } 3 \text { concepts: the quality of } \\
\text { the information (corresponding to the scientific validity of the variants } \\
\text { identified), the respect of rules and the welfare of the patient. They agreed on } \\
\text { the need to provide clear, personalised information to patients. } \\
\text { The researchers implemented various actions to prepare for the discovery of } \\
\text { secondary findings. These included: adding specific wording to the informed } \\
\text { consent document to clearly indicate how researchers will convey these data; } \\
\text { exploring how the participants should be prepared to make decisions, the way } \\
\text { in which they themselves would like to receive these secondary findings; } \\
\text { developing procedures for the disclosure and then individualised follow-up. }\end{array}$ \\
\hline
\end{tabular}




\begin{tabular}{|c|c|c|c|}
\hline $\begin{array}{l}\text { Simon et al., } \\
2011\end{array}$ & $\begin{array}{l}\text { Informed Consent and Genomic Incidental Findings: IRB } \\
\text { Chair Perspectives }\end{array}$ & $\begin{array}{l}34 \text { Chairs of institutional review boards } \\
\text { Semi-structured interviews } \\
\text { Aim: study the opinion of IRB members on the } \\
\text { return of secondary findings in a context of } \\
\text { informed consent processes }\end{array}$ & $\begin{array}{l}\text { General consensus on the importance of taking the choice of the patient into } \\
\text { account but also the evolution of such choices over time. }\end{array}$ \\
\hline $\begin{array}{ll}\text { Dressler } & \text { et } \\
\text { al., } 2012 & \end{array}$ & $\begin{array}{l}\text { IRB perspectives on the return of individual results from } \\
\text { genomic research }\end{array}$ & $\begin{array}{l}\text { Exome sequencing: research } \\
31 \text { reviewers } \\
\text { In-depth interviews } \\
\text { Aim: analyse the perspectives and the approaches } \\
\text { of IRB with regard to the return of secondary } \\
\text { findings in a research context. }\end{array}$ & $\begin{array}{l}\text { Secondary findings in a research context must be returned when they are } \\
\text { medically actionable, but only if the patient wants to know the result. The } \\
\text { majority of participants were aware of the need to develop guidelines, but did } \\
\text { not wish this to be done in isolation. }\end{array}$ \\
\hline $\begin{array}{l}\text { Townsend et } \\
\text { al., } 2012\end{array}$ & $\begin{array}{l}\text { "I Want to Know What's in Pandora's Box": Comparing } \\
\text { Stakeholder Perspectives on Incidental Findings in Clinical } \\
\text { Whole Genomic Sequencing }\end{array}$ & $\begin{array}{l}\text { Genome sequencing: diagnosis } \\
10 \text { Doctors } \\
8 \text { Patients, } 10 \text { persons representing society at large. } \\
\text { Debates following a guide, led by a moderator. }\end{array}$ & See Table 1a \\
\hline $\begin{array}{ll}\text { Downing } & \text { et } \\
\text { al., } 2013\end{array}$ & $\begin{array}{l}\text { Genetics specialists' perspectives on disclosure of genomic } \\
\text { incidental findings in the clinical setting }\end{array}$ & $\begin{array}{l}50 \text { geneticists } \\
\text { Structured telephone interviews. } \\
\text { Aim: examine the perspectives of geneticists with } \\
\text { regard to the disclosure of secondary findings. }\end{array}$ & $\begin{array}{l}\text { The problems encountered concerned the information given to patients and } \\
\text { the return of secondary findings. Participant underlined their concern about } \\
\text { causing psychological harm to patients. There was no consensus about } \\
\text { whether a secondary finding had to be clinically significant and/or actionable } \\
\text { to be returned to patients. They were in favour of creating guidelines, but only } \\
\text { if they were flexible enough to be adapted to individual situations. }\end{array}$ \\
\hline $\begin{array}{l}\text { Keogh et al., } \\
2014\end{array}$ & $\begin{array}{l}\text { How do researchers manage genetic results in practice? } \\
\text { The experience of the multinational Colon Cancer Family } \\
\text { Registry }\end{array}$ & $\begin{array}{l}\text { Exome sequencing: research } \\
6 \text { researchers representing } 6 \text { centres of the «Colon } \\
\text { Cancer Family Registry ». } \\
\text { Questionnaires: fixed-choice and open questions. } \\
\text { Aim: describe the protocols used to return clinically } \\
\text { pertinent results, report the use of these results, } \\
\text { examine the challenges raised by the return of these } \\
\text { results and propose recommendations for future } \\
\text { practice. }\end{array}$ & $\begin{array}{l}\text { This article showed the considerable problems of diversity, the challenges and } \\
\text { the costs encountered in practice, for the return of secondary findings whose } \\
\text { utility has been established. The difficulties the most often mentioned were: } \\
\text { the absence of guidelines, the problems in terms of cost and logistics due to } \\
\text { the signature of a second consent form, the limited implication of genetic } \\
\text { counsellors in certain centres. }\end{array}$ \\
\hline
\end{tabular}




\begin{tabular}{|c|c|c|c|}
\hline $\begin{array}{l}\text { Grove et al., } \\
2014\end{array}$ & $\begin{array}{l}\text { Views of genetics health professionals on the return of genomic } \\
\text { results }\end{array}$ & $\begin{array}{l}35 \text { members of ASHG or NSGC } \\
\text { Three focus groups }\end{array}$ & $\begin{array}{l}\text { Participant were divided into three focus group, entitled "Informed consent } \\
\text { and patient autonomy", "Challenges in the delivery of genomic medicine" and } \\
\text { "Categorizing incidental results". They thought that results should be returned } \\
\text { to the healthcare provider rather than directly to patient. They agreed on the } \\
\text { returning of pharmacogenetic results as they felt they were not stigmatizing, } \\
\text { but there were much debate regarding medically relevant results. Regarding } \\
\text { incidental results, healthcare providers would place genetic results into } \\
\text { categories and the patient would subsequently consent to those categories. }\end{array}$ \\
\hline $\begin{array}{l}\text { Kleiderman } \\
\text { et al., } 2015\end{array}$ & $\begin{array}{l}\text { Disclosure of incidental findings in cancer genomic research: } \\
\text { investigators' perceptions on obligations and barriers }\end{array}$ & $\begin{array}{l}\text { Exome sequencing: research } \\
20 \text { professionals } \\
\text { Semi-structured telephone interviews. } \\
\text { Aim: explore the perceptions and experiences of } \\
\text { investigators with regard to the return of secondary } \\
\text { findings in research }\end{array}$ & $\begin{array}{l}4 \text { context-dependent elements must be taken into account for the return of } \\
\text { results: the importance of the results, the respect of the choice of patients, the } \\
\text { implication of infrastructures, professional responsibility }\end{array}$ \\
\hline \multicolumn{4}{|c|}{ Mixed methodology (quantitative + qualitative) } \\
\hline $\begin{array}{l}\text { Klitzman et } \\
\text { al., } 2013\end{array}$ & $\begin{array}{l}\text { Researchers' views on return of incidental genomic research } \\
\text { results: qualitative and quantitative findings }\end{array}$ & $\begin{array}{l}234 \text { members of the US genetic research } \\
\text { community (survey) } \\
28 \text { genomic researchers (semi-structured interview) }\end{array}$ & $\begin{array}{l}95 \% \text { believe that incidental findings for highly penetrant disorders with } \\
\text { immediate medical implications should be offered to research participant and } \\
91.5 \% \text { for children, in case of clinically actionable variants before adulthood. } \\
60 \% \text { would disclose high penetrance variants without clinical intervention to } \\
\text { adults (vs } 48.5 \% \text { to children). } 54 \% \text { would disclose pharmacogenetic variants. } \\
\text { Researchers raised concerns that the return of incidental findings would } \\
\text { impose significant burdens on research and could potentially have deleterious } \\
\text { effects on research participants if not performed well. They believe } \\
\text { participants should have the choice to receive at least some incidental findings. }\end{array}$ \\
\hline
\end{tabular}




\begin{tabular}{|c|c|c|c|}
\hline $\begin{array}{l}\text { Appelbaum } \\
\text { et al., } 2014\end{array}$ & $\begin{array}{l}\text { Informed Consent for Return of Incidental Findings in } \\
\text { Genomic Research }\end{array}$ & $\begin{array}{l}\text { Exome sequencing: research } \\
20 \text { patients participating in a study } \\
\text { Mean age } 44 \text { years (semi-structured interviews) } \\
\mathbf{2 5 4} \text { researchers in genetics (internet survey) } \\
\mathbf{2 8} \text { genomic researchers (semi-structured } \\
\text { interviews) } \\
\text { Aim: provide suggestions to investigators to shape } \\
\text { the consent process for the return of secondary } \\
\text { findings in research }\end{array}$ & 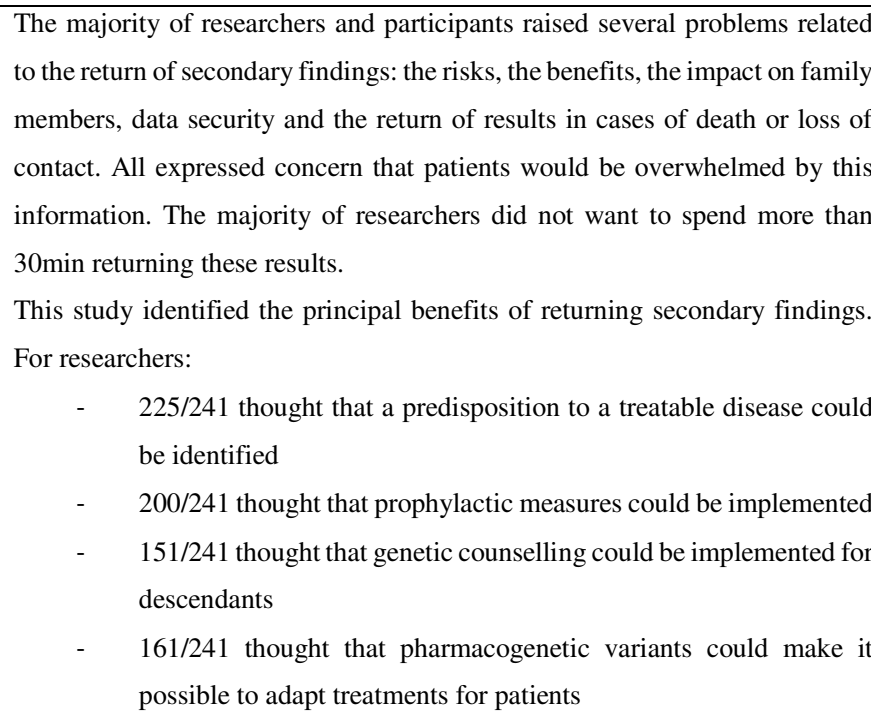 \\
\hline $\begin{array}{l}\text { Turbitt et al., } \\
2014\end{array}$ & $\begin{array}{l}\text { Availability of treatment drives decisions of genetic } \\
\text { health professionals about disclosure of incidental } \\
\text { findings }\end{array}$ & $\begin{array}{l}59 \text { Australian geneticists } \\
\text { Discrete-choice method } \\
\text { Aim: evaluate the most important characteristics } \\
\text { according to the doctors for the return of secondary } \\
\text { findings concerning children }\end{array}$ & $\begin{array}{l}\text { The most important criterion for the return of secondary findings was the } \\
\text { existence of preventive measures and treatments. Other notions, such as age } \\
\text { at the onset of symptoms in childhood, the severity and complete penetrance } \\
\text { were important. }\end{array}$ \\
\hline $\begin{array}{l}\text { Strong et al., } \\
2014\end{array}$ & $\begin{array}{l}\text { Views of primary care providers regarding } \\
\text { the return of genome sequencing incidental findings }\end{array}$ & $\begin{array}{l}\text { Exome sequencing: diagnosis } \\
258 \text { paediatricians } \\
\text { Survey. } \\
\text { Aim: evaluate the opinions of non-geneticist } \\
\text { doctors concerning the return of secondary } \\
\text { findings. }\end{array}$ & $\begin{array}{l}96 \% \text { of paediatricians wanted to know about actionable secondary findings of } \\
\text { adult-onset diseases affecting them ( } 56 \% \text { if non-actionable). Concerning their } \\
\text { children, } 91 \% \text { wanted to know the data for adult-onset diseases if actionable, } \\
47 \% \text { if non-actionable; for childhood-onset diseases, the figures were } 96 \% \text { if } \\
\text { actionable and } 68 \% \text { if non-actionable. }\end{array}$ \\
\hline
\end{tabular}




\begin{tabular}{|c|c|c|c|}
\hline $\begin{array}{l}\text { Gray et al., } \\
2016\end{array}$ & $\begin{array}{l}\text { Oncologists' and Cancer Patients' Views on Whole-Exome } \\
\text { Sequencing and Incidental Findings: Results from The CanSeq } \\
\text { Study }\end{array}$ & $\begin{array}{l}\text { Exome sequencing: research } \\
167 \text { patients } \\
27 \text { oncologists } \\
\text { Prospective study with surveys and interviews for } \\
\text { the doctors. } \\
\text { Aim: show how the introduction of WES in cancer } \\
\text { care could affect patients and oncologists. }\end{array}$ & $\begin{array}{l}78 \% \text { were in favour of returning secondary findings if the validity of the WES } \\
\text { data was clinically established. } 67 \% \text { were not in favour of restricting the return } \\
\text { of results to actionable genes only. } 52 \% \text { thought that patients could receive all } \\
\text { of the results they wanted and even raw sequencing data. }\end{array}$ \\
\hline $\begin{array}{l}\text { Middleton et } \\
\text { al., } 2016\end{array}$ & $\begin{array}{l}\text { Attitudes of nearly } 7000 \text { health professionals, genomic } \\
\text { researchers and publics toward the return of incidental results } \\
\text { from sequencing research }\end{array}$ & 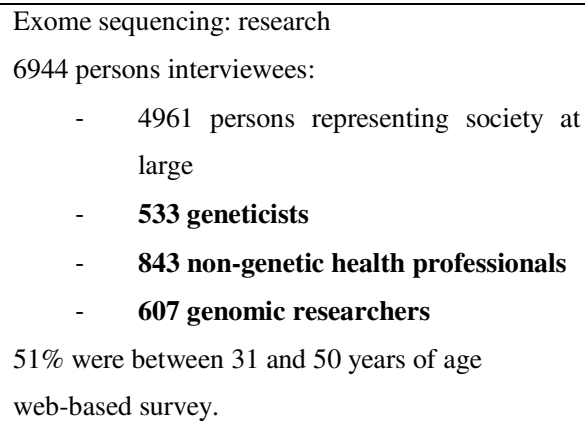 & $\begin{array}{l}\text { This article compared the points of view of healthcare professionals with those } \\
\text { of the general public. } \\
\text { In a research context, researchers were not expected to analyse secondary } \\
\text { findings opportunistically. Healthcare professionals were more conservative } \\
\text { than society at large (OR=7.21,95\% CI=5.19-10.03). } \\
96 \% \text { (1552/1617) of healthcare professionals wanted to propose to screen for } \\
\text { actionable secondary findings and } 65 \% \text { (1038/1600) for non-actionable } \\
\text { secondary findings. }\end{array}$ \\
\hline
\end{tabular}


Table 1c: Studies of opinions centred on society at large and classified according to their methodology: quantitative, qualitative or mixed (quantitative + qualitative).

\begin{tabular}{|c|c|c|c|}
\hline $\begin{array}{l}\text { Author / Year } \\
\text { of publication }\end{array}$ & Title & $\begin{array}{l}\text { Number of subjects } \\
\text { studied/Method }\end{array}$ & Main result \\
\hline \multicolumn{4}{|c|}{ Quantitative methodology } \\
\hline $\begin{array}{l}\text { Fleming et al., } \\
2015\end{array}$ & $\begin{array}{l}\text { Attitudes of the general public towards the } \\
\text { disclosure of individual research results and } \\
\text { incidental findings from biobank genomic } \\
\text { research in Australia }\end{array}$ & $\begin{array}{l}\text { Exome sequencing: research } \\
800 \text { Australians aged } 18 \text { years and } \\
\text { older, representative of the } \\
\text { Australian population. } \\
\text { Mean age } 58.2 \text { years } \\
\text { Telephone survey. }\end{array}$ & $\begin{array}{l}\text { The majority wanted to receive information on secondary findings if they were taking part in clinical studies. } \\
94 \% \text { wanted to receive «information that was important for their health or on the treatment of their disease », } \\
84 \% \text { « on their risk of being a carrier of an inherited genetic disease » } 70 \% \text { « wanted to receive information } \\
\text { not directly concerning their disease ». }\end{array}$ \\
\hline $\begin{array}{l}\text { Regier et al., } \\
2015\end{array}$ & $\begin{array}{l}\text { Societal preferences for the return of } \\
\text { incidental findings from clinical genomic } \\
\text { sequencing: a discrete-choice experiment }\end{array}$ & $\begin{array}{l}\text { Exome sequencing: diagnosis } \\
1200 \text { Canadians } \\
\text { Median age } 49 \text { years } \\
\text { Discrete-choice method }\end{array}$ & $\begin{array}{l}\text { The participants expressed interest in receiving findings for severe or very severe diseases with a lifetime risk } \\
\geq 80 \% \text {, for which there is an effective treatment, and for heterozygous variants associated with recessive } \\
\text { hereditary diseases. However, they expressed no interest in variants exposing them to diseases with no } \\
\text { available treatments or lifestyle interventions. Patients' preferences tended towards the possibility of having } \\
\text { the choice of what investigations to have }\end{array}$ \\
\hline $\begin{array}{l}\text { Middleton et } \\
\text { al., } 2016\end{array}$ & $\begin{array}{l}\text { Attitudes of nearly } 7000 \text { health } \\
\text { professionals, genomic researchers and } \\
\text { publics toward the return of incidental } \\
\text { results from sequencing research }\end{array}$ & $\begin{array}{l}\text { Exome sequencing: research } \\
6944 \text { including } 4961 \text { persons } \\
\text { representing society at large } \\
\text { Web-based survey. }\end{array}$ & $\begin{array}{l}\text { Concerning the general public, } 98 \% \text { (4199/4304) wanted to receive actionable secondary findings and } 73 \% \\
\text { (3146/4304) wanted to receive non-actionable secondary findings. }\end{array}$ \\
\hline $\begin{array}{l}\text { Hufnagel et al., } \\
2016\end{array}$ & $\begin{array}{l}\text { Adolescents' Preferences } \text { Regarding } \\
\text { Disclosure of Incidental Findings in } \\
\text { Genomic Sequencing That Are Not } \\
\text { Medically Actionable in Childhood }\end{array}$ & $\begin{array}{l}\text { Exome sequencing: research } \\
282 \text { students who had been given } \\
\text { information on secondary findings } \\
89 \% \text { between } 12 \text { and } 18 \text { years old } \\
11 \% \text { more than } 18 \text { years old } \\
\text { Survey }\end{array}$ & $\begin{array}{l}83 \% \text { wanted access to secondary findings that were non-actionable during childhood. } 72 \% \text { wanted to take part } \\
\text { in decision-making. } 73 \% \text { thought that the parents of children of less than } 12 \text { years old must have access to } \\
\text { this information. }\end{array}$ \\
\hline
\end{tabular}




\begin{tabular}{|c|c|c|c|}
\hline $\begin{array}{l}\text { Haga et al., } \\
2012\end{array}$ & $\begin{array}{l}\text { Public Perspectives } \quad \text { About } \\
\text { Pharmacogenetic Testing and Managing } \\
\text { Ancillary Findings }\end{array}$ & $\begin{array}{l}45 \text { inhabitants of North Carolina } \\
\text { divided into } 4 \text { focus groups. } \\
\text { Median age between } 40 \text { and } 49 \\
\text { years } \\
\text { Discussion led by a moderator. }\end{array}$ & $\begin{array}{l}\text { The study investigated the opinions of the public on carrying out hypothetical pharmacogenetic tests and on } \\
\text { the discovery of secondary findings during these tests. } \\
\text { The inhabitants were rather interested in the contribution of pharmacogenetics. } 3 \text { of the } 4 \text { groups recognised } \\
\text { the benefit of knowing the risk of adverse effects of treatments. They thought that the clinician should return } \\
\text { these results but they were apprehensive about receiving results concerning predispositions to late-onset } \\
\text { genetic diseases. }\end{array}$ \\
\hline $\begin{array}{l}\text { Townsend et } \\
\text { al., } 2012\end{array}$ & $\begin{array}{l}\text { "I Want to Know What's in Pandora's } \\
\text { Box": Comparing Stakeholder } \\
\text { Perspectives on Incidental Findings in } \\
\text { Clinical Whole Genomic Sequencing }\end{array}$ & $\begin{array}{l}\text { Exome sequencing: diagnosis } \\
10 \text { Doctors, } 8 \text { Patients } \\
7 \text { persons representing society at } \\
\text { large. } \\
\text { Debates following a guide, led by a } \\
\text { moderator. }\end{array}$ & See Table 1a \\
\hline $\begin{array}{l}\text { Daack-Hirsch } \\
\text { et al., } 2013\end{array}$ & $\begin{array}{l}\text { "Information is Information": A public } \\
\text { perspective on incidental findings in } \\
\text { clinical and research genome-based testing }\end{array}$ & $\begin{array}{l}\text { Exome sequencing: diagnosis and } \\
\text { research } \\
63 \text { divided into } 9 \text { groups } \\
\text { representing various populations: } \\
\text { African-Americans, Hispanics, } \\
\text { Clergy, Elderly persons. } \\
\text { Directed interviews and open } \\
\text { questions. }\end{array}$ & $\begin{array}{l}\text { The participants wanted to be informed about secondary findings in clinical as well as research contexts. They } \\
\text { wanted to be given the choice of being informed or not. The potential of personally benefiting from the } \\
\text { findings was the principal reason. }\end{array}$ \\
\hline $\begin{array}{l}\text { Christenhusz et } \\
\text { al., } 2015\end{array}$ & $\begin{array}{l}\text { Focus group discussions on secondary } \\
\text { variants and next-generation } \\
\text { sequencing technologies }\end{array}$ & $\begin{array}{l}50 \text { Belgians divided into } 8 \text { focus } \\
\text { groups of } 6 \text { or } 7 \text {. } \\
\text { Structured discussions led by a } \\
\text { moderator. }\end{array}$ & $\begin{array}{l}\text { As well as the medical and scientific aspects, the participants underlined the interest of taking the parent-child } \\
\text { relationship and the context into account. They did not want the results to be restricted to variants concerning } \\
\text { potentially deadly diseases. Several times, the members of a group used the same arguments to justify opposite } \\
\text { opinions. }\end{array}$ \\
\hline
\end{tabular}


Strong et al.,

2014

Views of Nonmedical, Health System
Professionals Regarding the Return of
Whole Genome Sequencing Incidental
Findings

97 participants at the meeting of the

Medical College of Wisconsin's

Billing and Collections Team

Multiple-choice questionnaire

$98 \%$ of women, $58 \%$ were older

than 45 years
The majority wanted to receive all types of information on secondary findings concerning:

$97 \%$ for actionable adult-onset diseases

- $\quad 81 \%$ for non-actionable adult-onset diseases

on the secondary findings concerning their children :

- $\quad 95 \%$ for actionable adult-onset diseases

$77 \%$ for non-actionable adult-onset diseases

99\% for actionable childhood-onset diseases

$84 \%$ for non-actionable childhood-onset diseases 
Table 2: Synthesis of percentages of favourable opinions for the overall return of SF according to their actionability and the diagnosis/research criterion, when the article gave such information

\begin{tabular}{|c|c|c|c|c|c|}
\hline Article & $\begin{array}{l}\text { Studied } \\
\text { Population }\end{array}$ & $\begin{array}{l}\text { Actionable Secondary } \\
\text { Findings }\end{array}$ & $\begin{array}{l}\text { Non-actionable } \\
\text { secondary findings }\end{array}$ & $\begin{array}{l}\text { Diagnosis } \\
\text { context }\end{array}$ & $\begin{array}{l}\text { Research } \\
\text { Context }\end{array}$ \\
\hline $\begin{array}{l}\text { Shahmirzadi et } \\
\text { al., 2013* }\end{array}$ & Participants & $187 / 200(94 \%)$ & & $\mathrm{x}$ & \\
\hline \multirow{2}{*}{$\begin{array}{l}\text { Fernandez et } \\
\text { al., 2014* }\end{array}$} & \multirow[t]{2}{*}{ Participants } & Adults: 312/321 (97\%) & $\begin{array}{l}\text { Adults: } 264 / 318 \\
(83 \%)\end{array}$ & & \multirow[t]{2}{*}{$\mathrm{x}$} \\
\hline & & $\begin{array}{l}\text { Minors: } 318 / 322 \\
(99 \%)\end{array}$ & $\begin{array}{l}\text { Minors: 281/316 } \\
(89 \%)\end{array}$ & & \\
\hline \multirow{2}{*}{$\begin{array}{l}\text { Fernandez et } \\
\text { al., } 2015^{*}\end{array}$} & \multirow[t]{2}{*}{ Participants } & \multirow{2}{*}{$\begin{array}{l}\text { Adults: } 141 / 146(97 \%) \\
\text { Minors: } 139 / 145 \\
(96 \%)\end{array}$} & Adults: $120 / 145$ & & \multirow[t]{2}{*}{$\mathrm{x}$} \\
\hline & & & $\begin{array}{l}(83 \%) \\
\text { Minors: } \\
\text { 122/143(85\%) }\end{array}$ & & \\
\hline $\begin{array}{l}\text { Jelsig et al., } \\
\text { 2015\# }\end{array}$ & Participants & $45 / 127(36 \%)$ & & & $\mathrm{x}$ \\
\hline $\begin{array}{l}\text { Gray et al., } \\
2016^{*}\end{array}$ & Participants & $159 / 167(95 \%)$ & $142 / 167(85 \%)$ & & $\mathrm{x}$ \\
\hline $\begin{array}{l}\text { Kaphingst et } \\
\text { al., 2016** }\end{array}$ & Participants & $60 / 60(100 \%)$ & & & $\mathrm{x}$ \\
\hline
\end{tabular}

\begin{tabular}{|c|c|c|c|c|c|}
\hline Total & Participants & $\begin{array}{l}\text { Overall population : } \\
894 / 1021(88 \%) \\
\text { Minors : } 457 / 467 \\
(98 \%)\end{array}$ & $\begin{array}{l}\text { Overall } \\
\text { population : } \\
526 / 630(83 \%) \\
\text { Minors : } 403 / 459 \\
(88 \%)\end{array}$ & & \\
\hline $\begin{array}{l}\text { Lohn et al., } \\
2012 *\end{array}$ & $\begin{array}{l}\text { Healthcare } \\
\text { providers }\end{array}$ & $\begin{array}{l}\text { Adults: 195/207 (94\%) } \\
\text { Minors: 199/207 } \\
(96 \%)\end{array}$ & $\begin{array}{l}\text { Adults: } 118 / 207 \\
(57 \%) \\
\text { Minors: } 83 / 207 \\
(40 \%)\end{array}$ & $\mathrm{x}$ & \\
\hline $\begin{array}{l}\text { Lemke et al., } \\
2013^{*}\end{array}$ & $\begin{array}{l}\text { Healthcare } \\
\text { providers }\end{array}$ & $\begin{array}{l}\text { Adults: } 268 / 279(96 \%) \\
\text { Minors: } 273 / 279 \\
(98 \%)\end{array}$ & $\begin{array}{l}\text { Adults: } 145 / 279 \\
(52 \%) \\
\text { Minors: } 195 / 279 \\
(70 \%)\end{array}$ & $\mathrm{x}$ & \\
\hline $\begin{array}{l}\text { Yu et al., } \\
\text { 2014\# }\end{array}$ & $\begin{array}{l}\text { Healthcare } \\
\text { providers }\end{array}$ & $571 / 800(71 \%)$ & & $\mathrm{x}$ & \\
\hline $\begin{array}{l}\text { Scheuner et al., } \\
2014 \#\end{array}$ & $\begin{array}{l}\text { Healthcare } \\
\text { providers }\end{array}$ & $\begin{array}{l}\text { Adults: } 352 / 492 \\
(71.5 \%) \\
\text { Minors: } 229 / 492 \\
(46.5 \%)\end{array}$ & & $\mathrm{x}$ & \\
\hline $\begin{array}{l}\text { Barajas and } \\
\text { Ross, 2015\# }\end{array}$ & $\begin{array}{l}\text { Healthcare } \\
\text { providers }\end{array}$ & $86 / 173(50 \%)$ & & $\mathrm{x}$ & \\
\hline Wynn et al., & Healthcare & Adults: $209 / 241(87 \%)$ & Adults: $121 / 241$ & & $\mathrm{x}$ \\
\hline
\end{tabular}


Strong et al., Healthcare 2014\# providers

Klitzman et al., Healthcare 2013* providers

Gray et al.

Healthcare providers

Middleton et al., 2016* providers
Adults: 235/242 (97\%) Adults: 177/243

$\mathrm{X}$

Minors: 234/243 (73\%)

$(96 \%)$

Minors: 191/244

(78\%)

Adults: 222/234 (95\%) Adults: 141/234

X

Minors: 214/234

$(60 \%)$

$(91.5 \%)$

Minors: $113 / 234$

$(48.5 \%)$

$14 / 27(52 \%)$

$\mathrm{x}$

$1038 / 1600(65 \%) \quad x$

$1552 / 1617(96 \%)$

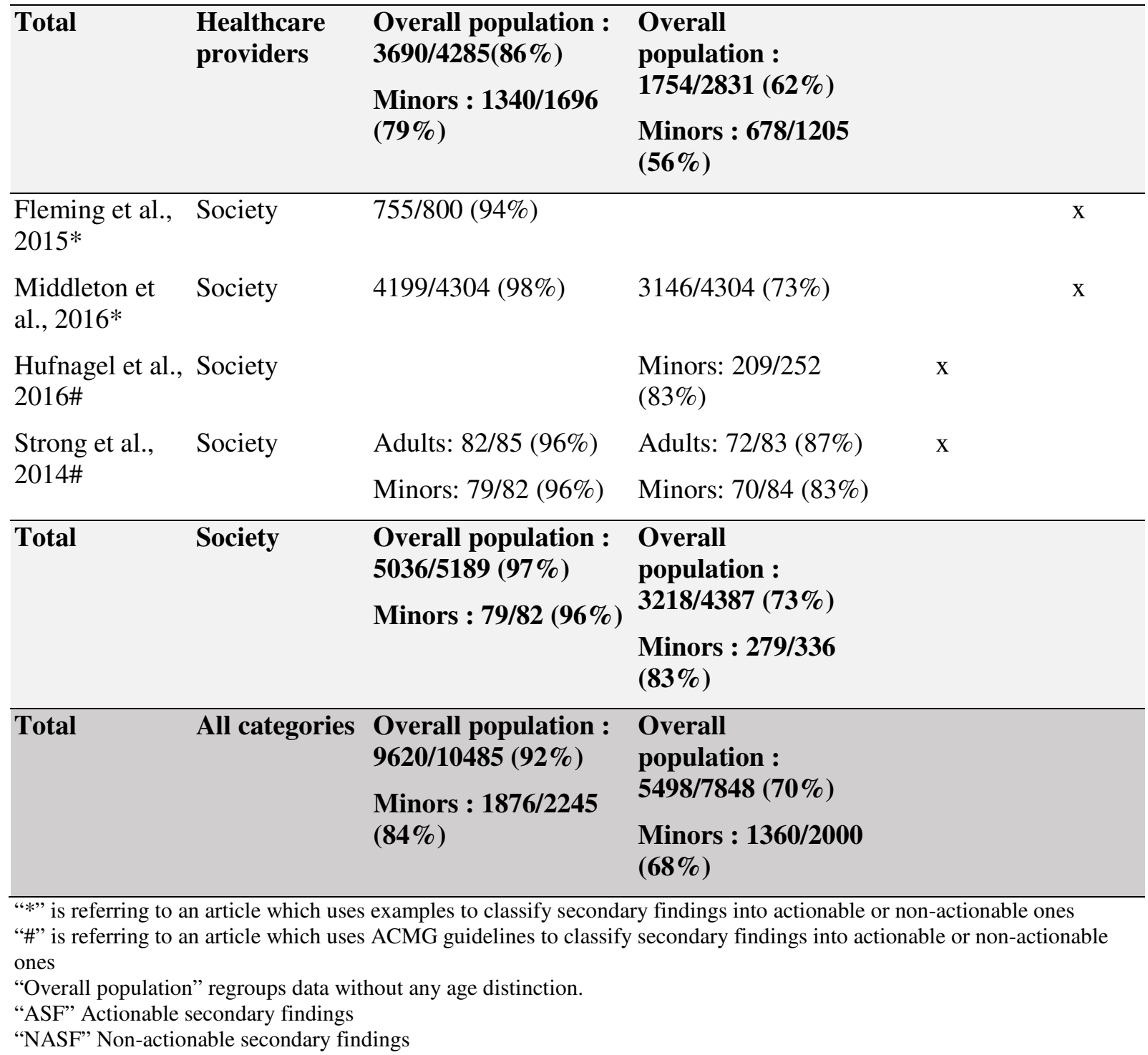

